\title{
ТЕНДЕНЦИИ ЗАБОЛЕВАЕМОСТИ, РАСПРОСТРАНЕННОСТИ И СМЕРТНОСТИ ОТ ВИЧ-ИНФЕКЦИИ И ТУБЕРКУЛЕЗА В РЕГИОНАХ РОССИИ В ХХІ ВЕКЕ
}

\author{
АЛЕКСЕЙ АСТРЕЛИН
}

\begin{abstract}
По официальным данным Роспотребнадзора, в России проживают свыше 1 млн человек с ВИЧинфекиией (ВИЧ), при этом число как новых случаев заражения, так и летальных исходов непрерывно растет в течение последних двух десятилетий. По тем же данным у 50\% зарегистрированных пациентов ВИЧ-инфекиия сочетается с туберкулезом (ТБ), а у свыше половины умерших от ВИЧ имела место клиническая картина прогрессирующего туберкулёза.

В настоящей работе представлены результаты пространственного анализа эпидемиологической ситуации с ВИЧ-инфекцией и туберкулёзом, в том числе предпринимается попьтка определения взаимосвязей развития эпидемии ВИЧ и туберкулёза на региональном уровне. Региональные тренды различаются между собой по больиинству рассматриваемых позиций: динамика заболеваемости, распространённости и смертности от этих инфекций неоднородна, регионь буквально ежегодно сменяют друг друга на «лидируюших» позищиях, что добавляет сложности к выделению ключевых факторов, влияющих на данные показатели. Макроуровневый анализ взаимосвязи распространённости и смертности от ВИЧ-инфекции и туберкулёза показал, что однозначно определить от чего конкретно зависит уровень смертности от ВИЧ невозможно, но он точно зависит от степени распространения ВИЧ на территории субъекта. В то же время достаточно достоверной взаимосвязи между распространённостью антиретровирусной терапии (АРВТ) $u$ смертностью от ВИЧ обнаружить не удалось, что может служить косвенным доказательством не только недостаточного распространения АРВТ (в России на 2019 г. только половина ВИЧпозитивных пацичентов получали терапию), но и недостаточной её эффективности, например из-за слишком позднего выявления ВИЧ или начала терапии.
\end{abstract}

Ключевые слова: ВИЧ, туберкулёз, ВИЧ-ТБ, коинфекция, заболеваемость, распространенность, смертность.

\section{ВВЕДЕНИЕ}

В настоящее время эпидемия ВИЧ-инфекции (ВИЧ) входит в число глобальных вызовов развитию социальной сферы и здравоохранения в большинстве стран мира. Россия не является исключением. Высокая распространенность и смертность от ВИЧ, также как и от туберкулёза (ТБ) - важнейшие проблемы Российской Федерации на сегодняшний день.

По данным Федерального научно-методического Центра по профилактике и борьбе со СПИДом, на 1 января 2019 г. в России насчитывалось 1048498 людей, живущих с ВИЧ (714 человек на 100 тыс. населения), а заболеваемость за 2018 г. составила более 70 человек на 100 тыс. населения.

АЛЕКСЕЙ МИХАЙЛОВИч АСТРЕЛИН (amastrelin@edu.hse.ru), НАЦИОНАЛЬНЫЙ ИССЛЕДОВАТЕЛЬСКИЙ УНИВЕРСИТЕТ «ВЫСШАЯ ШКОЛА ЭКОНОМИКИ», РОССИЯ.

СТАТЬЯ ПОСТУПИЛА В РЕДАКЦИЮ В СЕНТЯБРЕ 2020 Г. 
В Российской Федерации наблюдается ежегодный рост стандартизованного коэффициента смертности от ВИЧ-инфекции, а половина пациентов, зарегистрированных, как умершие от ВИЧ, умирают от прогрессирования туберкулёза. Кумулятивное число зараженных на конец 2018 г. превышает 1300 тыс. человек, а умерших от ВИЧ - более 280 тыс. человек (Федеральный научно-методический центр... 2019).

Туберкулёз, сочетающийся с ВИЧ-инфекцией (коинфекция), опасен наличием ряда возможных негативных последствий для развития болезни (высокая частота случаев развития туберкулёза с множественной лекарственной устойчивостью (МЛУ-ТБ), более низкая доля успешного лечения пациентов с сочетанием ТБ/ВИЧ в сравнении с лечением пациентов, зараженных только одной болезнью). Даже в самом преуспевающем в лечении подобных болезней Европейском регионе по данным ВОЗ доля больных с сочетанием ТБ/ВИЧ, успешно завершивших лечение туберкулёза в 2018 г., составляла порядка 62\%, в то время как среди остальных больных она была 76\% (World Health Organization 2019).

По данным Центрального научно-исследовательского института организации и информатизации здравоохранения, в России с начала XXI века улучшается эпидемическая ситуация по туберкулезу, о чем свидетельствует динамика основных эпидемиологических показателей. Но данный факт не является бесспорным, в современной России происходили изменения в статистическом учёте болезни, а также высока вероятность того, что по мере распространения эпидемии ВИЧ-инфекции возможен рост доли пациентов с поздними стадиями ВИЧ и рост доли пациентов с множественной лекарственной устойчивостью микобактерий туберкулеза к противотуберкулезным препаратам (Нечаева 2017а). То есть ухудшение ситуации с ВИЧ не позволит ситуации с ТБ существенно улучшиться, а приведёт к росту заболеваемости и летальности пациентов с туберкулезом в ряде российских регионов. Даже если признать, что эпидемиологическая ситуация с туберкулёзом улучшается, Россия, по данным Всемирной Организации Здравоохранения, остается в числе стран с высоким бременем туберкулёза (World Health Organization 2019).

Заболеваемость туберкулезом пациентов с ВИЧ-инфекцией среди постоянного населения России в 2019 г. составила 1 667,4 на 100 тыс. пациентов. Это в 60 раз превышает показатели по России в среднем без учёта пациентов, инфицированных ВИЧ (27,4 на 100 тыс. населения) (ФГБУ «ЦНИИОИЗ» Минздрава... 2019).

Эпидемическая ситуация по обеим болезням в стране значительно разнится от региона к региону. В 2018 г. в России были отмечены субъекты федерации, где выявление новых случаев заражения ВИЧ на 100 тыс. населения не превышало 20 человек (в основном это регионы Юго-Запада страны), а также те, где число заражений превышало 130 человек (регионы Сибири и Урала). Та же ситуация и с общим числом живущих с ВИЧ: на Кавказе этот показатель на 100 тыс. населения менее 100 человек, а в подавляющем большинстве сибирских и уральских регионов - более 1 тыс. (Федеральный научно-методический центр... 2019). Подобная дифференциация характерна для всех показателей эпидемиологической ситуации. Исходя из вышесказанного, мы считаем важным уделить внимание региональным аспектам распространения рассматриваемых заболеваний.

Несмотря на большое количество исследований, проводимых в данной области (Покровский, Ладная, Покровская 2017; Нечаева 2013; 2017b; 2019; Цыбикова, Владимиров 
2015; Цыбикова, Пунга, Русакова 2018), что обусловлено высокой актуальностью проблемы, и тот факт, что изучение региональных особенностей смертности в России часто становится объектом исследования отечественных демографов, в научной литературе на сегодняшний день не находится работ, посвященных комплексному изучению региональной специфики эпидемической ситуации с ВИЧ и ТБ и в которых бы уделялось внимание сочетанной инфекции, поэтому данное исследование представляется нам актуальным.

\section{ДАННЫЕ И МЕТОДЫ}

Под заболеваемостью в настоящей работе мы понимаем частоту новых случаев выявления заболевания, т.е. первичную заболеваемость. В России статистика новых случаев выявления ВИЧ формируется двумя структурами: Роспотребнадзором и Росстатом. Роспотребнадзор агрегирует данные лабораторных анализов, давших положительный результат (форма ФГСН №4). Соответственно, в статистику заболеваемости Роспотребнадзора идут все случаи, когда был получен подтвержденный положительный результат теста на ВИЧ. Росстат опирается на данные медицинских организаций и соответственно учитывает только тех людей, которые встали на диспансерный учёт (форма ФГСН №61). Число людей, у которых обнаружен ВИЧ, и число людей, вставших на учёт, не может быть равным. Люди могут бояться огласки, долго ждать, не вставать на учёт, заниматься самолечением и др. Лабораторные анализы один и тот же человек может сдать несколько раз, и в случае их положительного результата это завысит реальную ситуацию, но по информации Центра СПИД данные случаи исключены: дублирующие данные проверяются и исключаются из статистики ${ }^{1}$. Исходя из этого, статистика заболеваемости и распространенности Роспотребнадзора представляется более полной.

Число новых случаев выявления туберкулёза и сочетанной инфекции фиксируется Росстатом. В данном случае заболеваемость туберкулёзом нами оценивается, исходя из данных, представленных в форме ФГСН №8 «Туберкулёз впервые зарегистрирован».

Под распространенностью нами понимается кумулятивное число зарегистрированных больных на конец отчетного периода (за вычетом умерших), т.е. контингент лиц, состоящих на учете.

Одним из ограничений исследования распространенности ТБ является тот факт, что в российских регионах не ставятся на учёт пациенты, не зарегистрированные по постоянному месту жительства в данном субъекте РФ. Аналогична ситуация и для иностранцев, много лет проживающих в субъектах РФ. То есть туберкулёз был выявлен, пациента лечили, но на диспансерный учёт он поставлен не был и в статистику противотуберкулезных организаций не попал (Нечаева, Подымова 2018), а значит, реальная распространенность туберкулеза несколько занижена.

\footnotetext{
${ }^{1}$ В России до сих пор нет системного подхода к борьбе с ВИЧ. Спид.Центр. URL: https://spid.center/ru/articles/1137/
} 
В случае с ВИЧ такое же ограничение будет существовать, если мы будем опираться на данные Росстата (в 2016 г. была введена новая форма ФГСН №61, в результате чего часть впервые выявленных пациентов с бессимптомным статусом перестали попадать в отчетность: выявленные в местах лишения свободы; лица без определенного места жительства - БОМЖ; живущие в одних субъектах, но зарегистрированные в других). В статистику не попадают и иностранцы, хотя, согласно некоторым оценкам (Pokrovskiy 2014; Михайлова и др. 2018), массовая сезонная трудовая миграция (особенно из республик Средней Азии и Кавказа) переносит ВИЧ и ТБ в Россию. Исходя из этих ограничений, в настоящем исследовании распространенность ВИЧ измеряется числом подтвержденных положительных тестов (статистика Роспотребнадзора) в пересчете на 100 тыс. населения.

Распространенность ТБ и ВИЧ-ТБ измеряется числом пациентов, состоящих на учёте (форма ФГСН № 33) в пересчете на 100 тыс. населения.

В последние годы в российской статистике присутствует завышение показателя «смертность от ВИЧ-инфекции», которое сопровождается занижением показателей смертности от туберкулёза (Нечаева 2015; Нечаева, Подымова 2018). Это связано с особенностями статистического учёта, поскольку абсолютное большинство летальных исходов, наступивших в результате сочетанных заболеваний ТБ/ВИЧ, регистрируются как смерть от ВИЧ-инфекции (ФГБУ «ЦНИИОИЗ» Минздрава... 2017а). Более того, смерть от ВИЧ-инфекции регистрируется даже тогда, когда показатели иммунитета не вызывают опасений, и в статистику умерших от ВИЧ попадают пациенты, у которых вирусная нагрузка была ниже порога определения (ФГБУ «ЦНИИОИЗ» Минздрава... 2017b).

Так, в результате особенностей кодирования основной причины смерти в медицинском свидетельстве о смерти в 2018 г. почти 98\% случаев коморбидной патологии зафиксированы в статистических отчетах как смерть от ВИЧ-инфекции даже при высоких показателях количества CD-клеток (ФГБУ «ЦНИИОИЗ» Минздрава... 2018). Естественно, что в этом случае показатели смертности от туберкулёза снизились, но на деле произошел переброс в другую нозологическую форму.

За неимением более корректных данных анализ смертности в нашей работе проведён с использованием показателей российской базы данных (БД) по рождаемости и смертности Центра демографических исследований Российской Экономической Школы (РосБРиС ЦДИ РЭШ). В демографическую статистику БД РЭШ попадают все случаи по указанию первоначальной причины смерти, т. е. в нашей работе под смертностью от ВИЧ понимается число случаев смерти с указанием первоначальной причины «ВИЧ» и под смертностью от ТБ - число случаев с указанием первоначальной причины «ТБ». В качестве показателей, отражающих смертность, мы используем возрастные коэффициенты смертности (ВКС) и стандартизованный коэффициент смертности (СКС; за стандарт принято «стандартное европейское население» (The 1976 ESP)).

Временные рамки ограничиваются XXI веком, так как только в начале нулевых ВИЧ начал получать широкое распространение, тогда как туберкулёз уже преодолел все пики своего развития. 


\section{РезУльтаты}

\section{Заболеваемость}

Наибольшее значение заболеваемости туберкулёзом было зафиксировано в России в 2000 г. (90,4 на 100 тыс. человек), затем показатель начал снижаться, особенно быстро это происходило с 2008 г.: в 2008 г. - 85 на 100 тыс. чел., в 2018 г. - уже 44,4 (сократился на $47 \%$ ), а в 2019 г. - 41,2 (т. е. снизился ещё на 7,2\%).

Показатели распространенности ТБ за этот период также значительно сократились с 190,7 в 2008 г. до 101,6 в 2018 г. и 86,4 в 2019 г. (ФГБУ «ЦНИИОИЗ» Минздрава... 2017а; 2018, 2019). По прогнозу О.Б. Нечаевой (Нечаева 2019), заболеваемость туберкулёзом в России к 2028 г. сократится еще в 2 раза.

За последние 10 лет показатель первичной заболеваемости туберкулёзом среди населения, не инфицированного ВИЧ, в России сократился практически вдвое, а доля болеющих по полу и типу места жительства практически не изменялась: в 2019 г. среди всех заболевших ТБ 68,2\% - мужчины (70\% в 2009 г.) и почти $72 \%$-горожане (70\% в 2009 г.).

Практически на одном уровне остаётся возрастная структура заболеваемости: она немного «стареет», но всё равно наиболее подверженной заболеванию остаётся группа возрастов 18-44 года.

На конец 2018 г. показатель заболеваемости ВИЧ (по данным Роспотребнадзора) составлял 70,8 на 100 тыс. населения. 20 лет назад в 1998 г. он был равен 0, с 2003 г. и до настоящего времени неизменно рос (Федеральный научно-методический центр... 2019). При оценке заболеваемости ВИЧ важно также обратиться и к данным Росстата, так как в них учтён статус формы заболевания. В 2019 г. показатель заболеваемости ВИЧ-инфекцией (по форме ФГСН №61) составлял 60,8 на 100 тыс. населения, в том числе на коды В20-В24 (болезнь с выраженной симптоматикой) приходилось 56,1 случаев заболевания на 100 тыс. населения (это 96\% случаев). На код Z21 (бессимптомный статус) пришлось лишь 4\%, что свидетельствует о том, что на ранних стадиях развития инфекции ВИЧ практически не выявляется (Нечаева 2019).

Значительную часть зараженных ВИЧ-инфекцией составляет группа 20-40 лет, но доля группы 20-30 лет в распределении новых случаев заболевания ВИЧ к 2019 г. сократилась более чем в 2 раза, а группы 30-40 лет возросла в 5 раз, также увеличилась на 25\% доля группы 40-50 лет. На остальные возраста приходится менее 10\% (Федеральный научно-методический центр... 2019). В первом полугодии 2020 г. в 86\% случаев выявления ВИЧ пациенту было более 30 лет. На группу 30-50 лет пришлось 72,1\% всех случаев. Заболевают ВИЧ преимущественно мужчины, но и доля женщин с 2000-х годов несколько увеличивается и в последнее время стабильно находится на уровне порядка $35 \%$ (Федеральный научно-методический центр... 2019).

Изменение соотношения мужчин и женщин среди новых заражений объясняют меняющимися факторами риска: в начале нулевых практически 90\% пациентов заболевали при употреблении наркотиков, а так как мужчины являются основными потребителями 
наркотиков, то их доля среди заболевших была очень высока (Покровский, Ладная, Покровская 2017). Затем ВИЧ всё чаще и чаще начинает передаваться при гетеросексуальном контакте (Там же), соответственно, растёт доля заболевших женщин. «Старение» заболеваемости также частично связывают с наркотиками, а именно со взрослением потребителей внутривенных препаратов (Там же).

Большинство больных, впервые выявленных в 2020 г. (по состоянию на 30.09.2020), заразились при гетеросексуальных контактах (65,0\%), а доля инфицированных ВИЧ посредством употребления наркотиков снизилась до 31,5\% (Федеральный научнометодический центр... 2020b).

Выше мы уже говорили о моноварианте туберкулёза. Что касается заболеваемости туберкулезом пациентов с ВИЧ-инфекцией, то в 2019 г. она составила 1 667,4 на 100 тыс. пациентов, что в 61 раз больше, чем в среднем в населении России без инфицированных ВИЧ (27,4 на 100 тыс. населения). Важно, что растет разница между показателями заболеваемости туберкулезом ВИЧ-положительного и ВИЧ-негативного населения. В 2009 г. заболеваемость населения, не инфицированного ВИЧ, составляла 62,4 на 100 тыс. человек (разница в 30 раз); в 2018 г. - 30,1 (разница в 59 раз) (Стерликов 2018; ФГБУ «ЦНИИОИЗ» Минздрава... 2018).

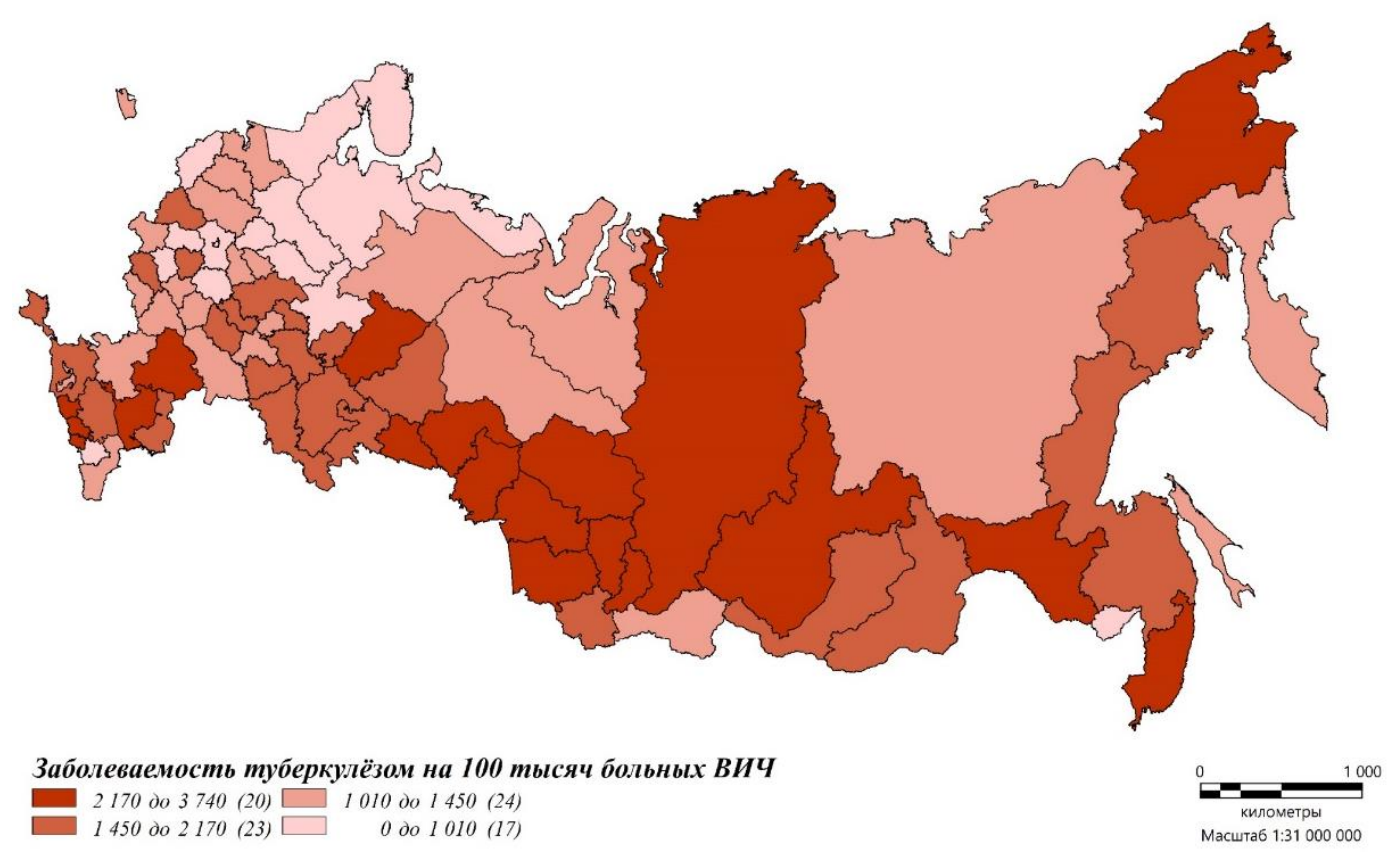

Рисунок 1. Заболеваемость туберкулёзом на 100 тыс. больных ВИЧ, 2018

Источник: Составлено автором по (ФГБУ «ЦНИИОИЗ» Минздрава... 2018).

Наиболее подвержены заболеваемости туберкулёзом ВИЧ-инфицированные в регионах Сибири (рисунок 1): во всех субъектах СФО, кроме Республики Тыва и Республики Алтай заболеваемость в 2018 г. была более 2 тыс. на 100 тыс. больных ВИЧ, чуть меньше показатели заболеваемости на Урале и в Поволжье (в среднем порядка 1,5 тыс. на 100 тыс. больных ВИЧ), Центр и Северо-Запад зачастую выделяются наименьшими показателями (менее 1 тыс. заболевших ТБ на 100 тыс. зараженных ВИЧ). 
Наиболее высок риск заболевания коинфекцией у молодых безработных мужчин, употреблявших инъекционные наркотики или имевших опыт тюремного заключения (Маньшина и др. 2017).

Важно заметить, что в первом полугодии 2020 г. в России было сообщено о 38126 новых случаях выявления ВИЧ в иммунном блоте, это на 20,5\% меньше, чем за аналогичный период 2019 г. Такое резкое снижение случаев выявления инфекции может быть связано с уменьшением объема обследований на ВИЧ и снижением количества обращений в Центры по профилактике и борьбе со СПИДом из-за осуществления противоэпидемических мероприятий по коронавирусной инфекции COVID-19. В I полугодии 2020 г. было обследовано на ВИЧ более 16,5 млн российских граждан, что составляет $11,3 \%$ от численности постоянного населения страны, но количество тестов уменьшилось на 15,7\% по сравнению с аналогичным периодом 2019 г. (Федеральный научно-методический центр... 2020а.).

\section{Распространенность}

На начало 2019 г. 2\% всех женщин и 3,3\% всех мужчин России в возрасте 35-39 лет были заражены ВИЧ-инфекцией. Ещё по 1,5\% обоих полов было заражено в возрастной группе 30-34 года и 3\% мужчин и 1,2\% женщин в группе 40-44 года (рисунок 2).

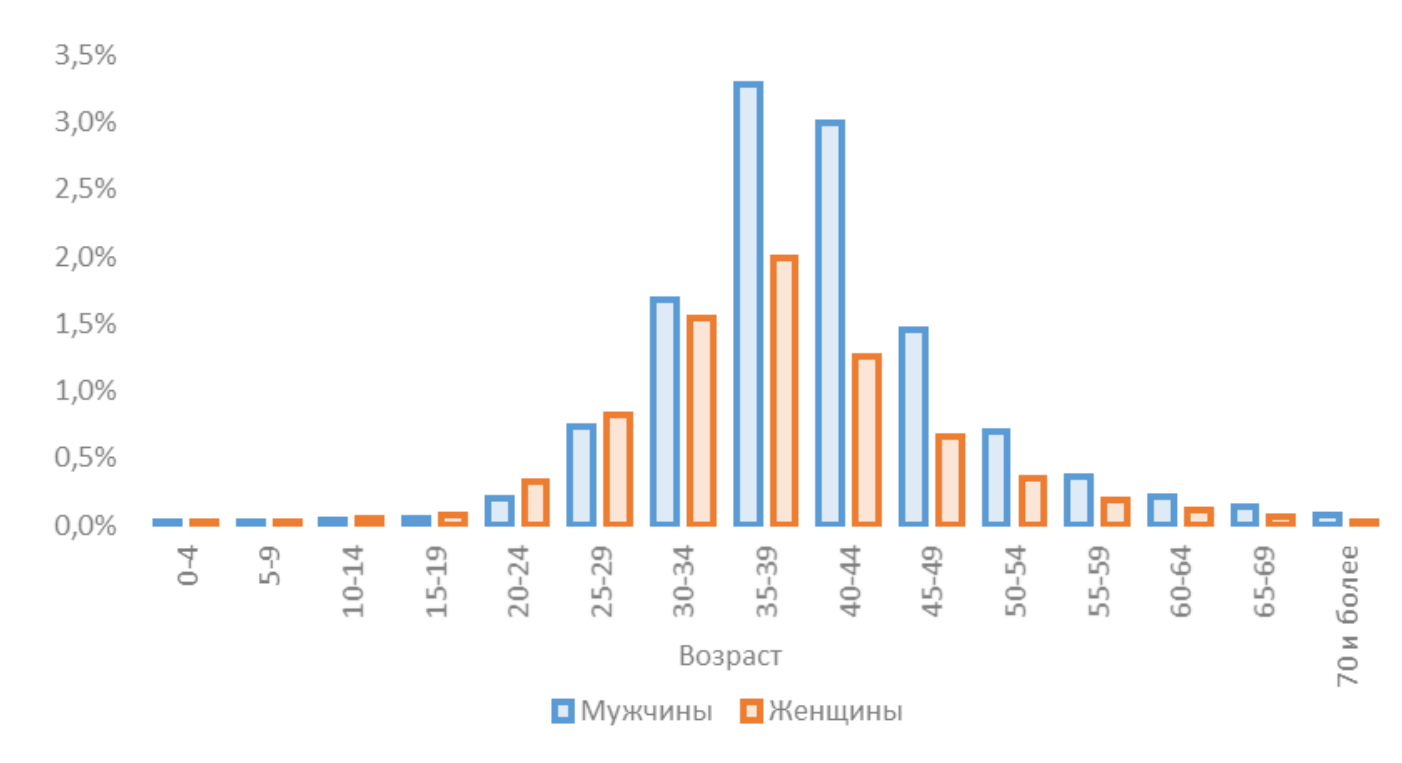

\section{Рисунок 2. Распространенность ВИЧ по полу и возрасту на 31.12.2018, \% от всего населения}

Источник: Составлено автором по (Федеральный научно-методический центр ... 2019).

Распространенность ВИЧ-инфекции на 30 сентября 2020 г. составила 747,7 на 100 тыс. населения России. Число регионов с высокой распространенностью ВИЧ (более 0,5\% от всего населения) постоянно растёт (в 2014г. - 22 субъекта, в 2020 г. - 38). В этих неблагополучных регионах на первую половину 2020 г. приходилось 84,0\% всех инфицированных ВИЧ (Федеральный научно-методический центр... 2020b). 
Наихудшая ситуация с распространенностью ВИЧ-инфекции была отмечена в двух Сибирских регионах: в Иркутской и Кемеровской областях на конец 2018 г. показатели распространенности превышали 1850 на 100 тыс. человек (рисунок 3; нумерация регионов указана в таблице Приложения), но и в других регионах Сибири, а также Поволжья и Урала показатели распространенности также значительны.

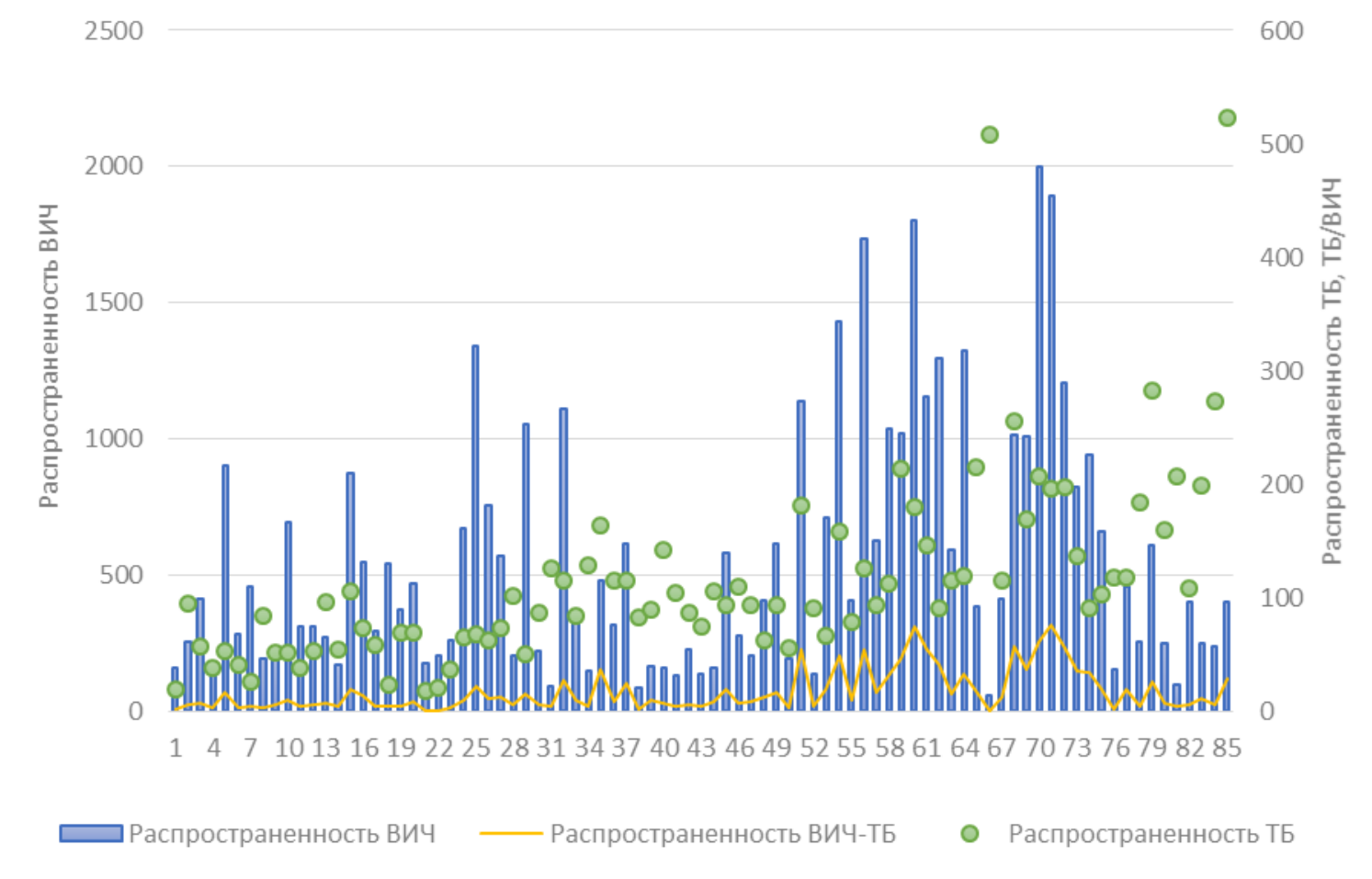

Рисунок 3. Распространенность ВИЧ, ТБ и ТБ/ВИЧ на 31.12. 2018, на 100 тыс. чел.

Источник: Составлено автором на основе данных (Федеральный научно-методический центр... 2019; ФГБУ «ЦНИИОИЗ» Минздрава... 2018).

Среди всех случаев заражения ВИЧ в России контингенты ФСИН составляют порядка 7\%, однако регионы значительно различаются по данному показателю (рисунок Приложения). Доля лиц, находящихся в местах лишения свободы, может как составлять менее 5\% от численности населения региона (регионы Дальнего Востока и Юга России), так и превышать 15-20\% (в основном Северо-Западные регионы).

На рисунке 3 представлено сравнение распространенности ВИЧ, ТБ и ТБ/ВИЧ. Можно заметить, что такие регионы, как Чукотский АО, Республика Тыва и Еврейская АО отличаются высокой распространенностью туберкулёза (523,5; 508,3; 272,7 на 100 тыс. человек соответственно), но в то же время по масштабам распространения ВИЧ они находятся далеко от первых позиций: например, Тува занимает последнее место с показателем в 55,2 на 100 тыс. человек (это в 30 раз меньше лидера - Иркутской области $(1997,7)$. Зачастую регионы-лидеры по распространению ВИЧ оказываются регионами с незначительным распространением туберкулёза и наоборот. Наиболее высокое распространение сочетанной инфекции отмечается в тех регионах, где значительное распространение получила ВИЧ-инфекция, что служит подтверждением того факта, что туберкулёзом заболевают преимущественно ВИЧ-инфицированные контингенты. 
В отличие от заболеваемости показатель распространённости уменьшается часто не из-за того, что пациентов вылечили, а из-за того, что наступила смерть пациентов с ТБ от разных причин (в большинстве случаев - от ВИЧ). Об этом мы можем судить, анализируя соотношение числа пациентов, которые вылечились от туберкулёза, и пациентов, которые умерли от ТБ и других причин. Этот показатель за последние годы улучшился, но минимально и составлял в 2012 г. - 3, в 2017 г. - 2,87, в 2018 г. - 2,81 (ФГБУ «ЦНИИОИЗ» Минздрава... 2018: 9).

Распространенность сочетанной инфекции гораздо менее значительна, чем моновариантов болезней: на 100 тыс. человек в 11 субъектах она превышает 40, в 10 превышает 20, также довольно много субъектов, где распространенность не превышает и 10. Высоко распространение коинфекции в регионах Сибири и Урала, наименьшее распространение - в регионах Северо-Запада.

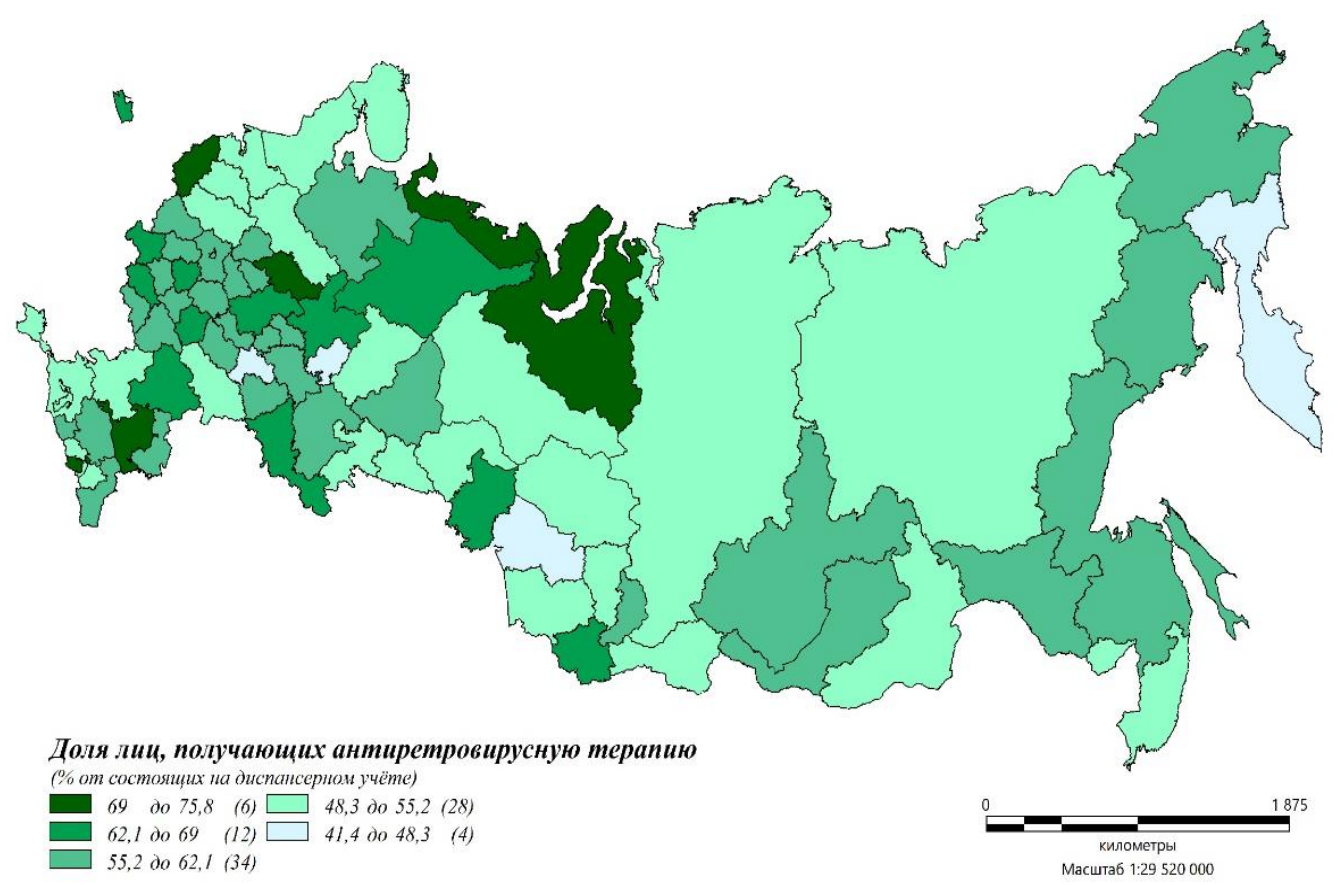

Рисунок 4. Доля лиц, получающих антиретровирусную терапию, среди всех, состоящих на диспансерном учёте на 2018 г., \%

Источник: Составлено автором по (Федеральный научно-методический центр... 2019).

Стоит отметить, что на 30 сентября 2020 г. антиретровирусную терапию получали 581,5 тыс. пациентов (Федеральный научно-методический центр... 2020b) - это только половина от всех живущих с ВИЧ. Но мы можем наблюдать положительную динамику: например, за 2019 г. более 100 тыс. инфицированных ВИЧ получили терапию впервые, а кумулятивно за 2018 г. АРВТ получали более 400 тыс. человек (для сравнения: в 2014 г. таковых было 178 тыс. или 24\% от всех живущих с ВИЧ) (Федеральный научнометодический центр... 2020b). В 32 регионах 55\% людей не получает АРВТ; в основном это регионы Сибири, Урала и Северо-Запада России (рисунок 4). Большая часть регионов характеризуется обеспеченностью АРВТ на уровне 55-62\%, сюда попадают в основном регионы Центра и некоторые регионы Дальнего Востока, Поволжья. 


\section{Смертность}

К 30 июля 2020 г. умерло 25,3\% от числа всех зарегистрированных инфицированных ВИЧ россиян. Всего за 2019 г. в Российской Федерации умерло от всех причин 33,5 тыс. больных ВИЧ-инфекцией, в 2018 г. - 36,8 тыс., в первом полугодии 2020 г. - 14,4 тыс. Умирают ВИЧ-позитивные в молодом возрасте: средний возраст смерти 39 лет. Ведущей причиной летальных исходов остается туберкулез (Федеральный научнометодический центр... 2020а).

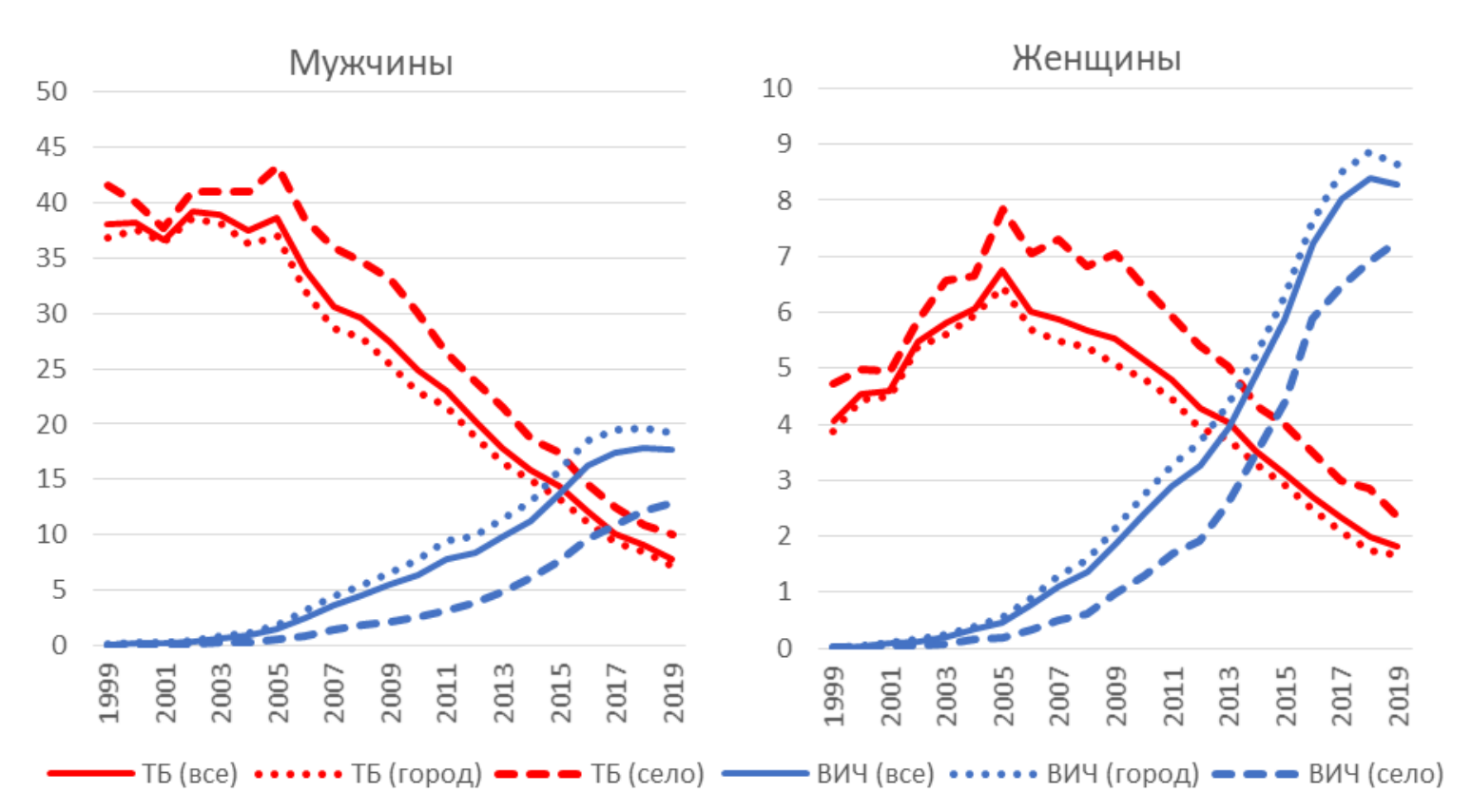

\section{Рисунок 5. Стандартизованный коэффициент смертности от ВИЧ и туберкулёза в России за 1999-2019 гг., на 100 тыс. чел.}

Источник: Составлено автором на основе данных (Российская экономическая школа 2019).

На рисунке 5 отчётливо видны тенденции роста смертности от ВИЧ и снижения - от туберкулёза, а также разница между полами: по сути, и ВИЧ, и ТБ можно считать «мужскими» болезнями (2/3 всех случаев заболеваемости и смертности).

Причём, на протяжении рассматриваемого временного отрезка наибольшие показатели смертности от ВИЧ наблюдались у мужчин-горожан, а от туберкулёза у жителей сел. На 100 тыс. человек в 2019 г. стандартизованный коэффициент смертности (СКС) от туберкулёза у мужчин составлял 7, у женщин - 1,6; от ВИЧ у мужчин - 17,65, у женщин $-8,6$.

Также можно заметить, что у городских мужчин с 2016 г. рост смертности от ВИЧ несколько замедлился (прирост за 3 года составил менее 5\%), причем 2019 г. стал первым, когда СКС снизился, хоть и незначительно. Но вот у сельских мужчин за тот же период показатель вырос на 33\%. Конечно, существует вероятность, что смертность от ВИЧинфекции среди сельских жителей начнёт активнее расти и, возможно, уже скоро «догонит» городскую. 


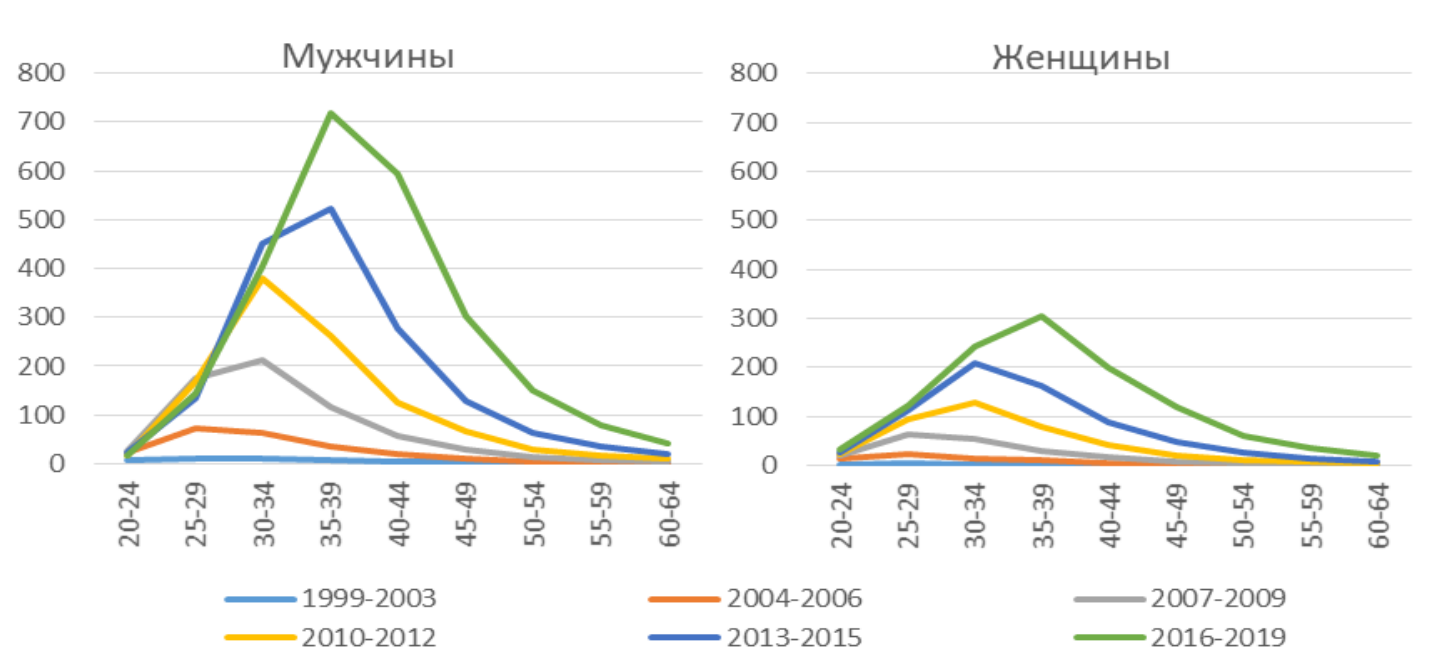

\section{Рисунок 6. Возрастные коэффициенты смертности от ВИЧ-инфекции 1999-2019 гг. (на 1000 тыс. чел.)}

Источник: Составлено автором на основе данных (Российская экономическая школа 2019).

Умирают люди от ВИЧ-инфекции, главным образом, в молодых трудоспособных возрастах (рисунок 6). Наиболее часто смерти происходят в возрастных группах от 30 до 44 лет, причем, если пик смертности одинаков и у мужчин, и у женщин (35-39 лет), то на втором месте по смертности у мужчин находится возрастная группа 40-44 года, а у женщин -30-34 года.

Что касается возрастных коэффициентов смертности от туберкулёза (рисунок 7), то здесь разница между возрастными группами прослеживается гораздо слабее, особенно в последние годы, чем в показателях смертности от ВИЧ.

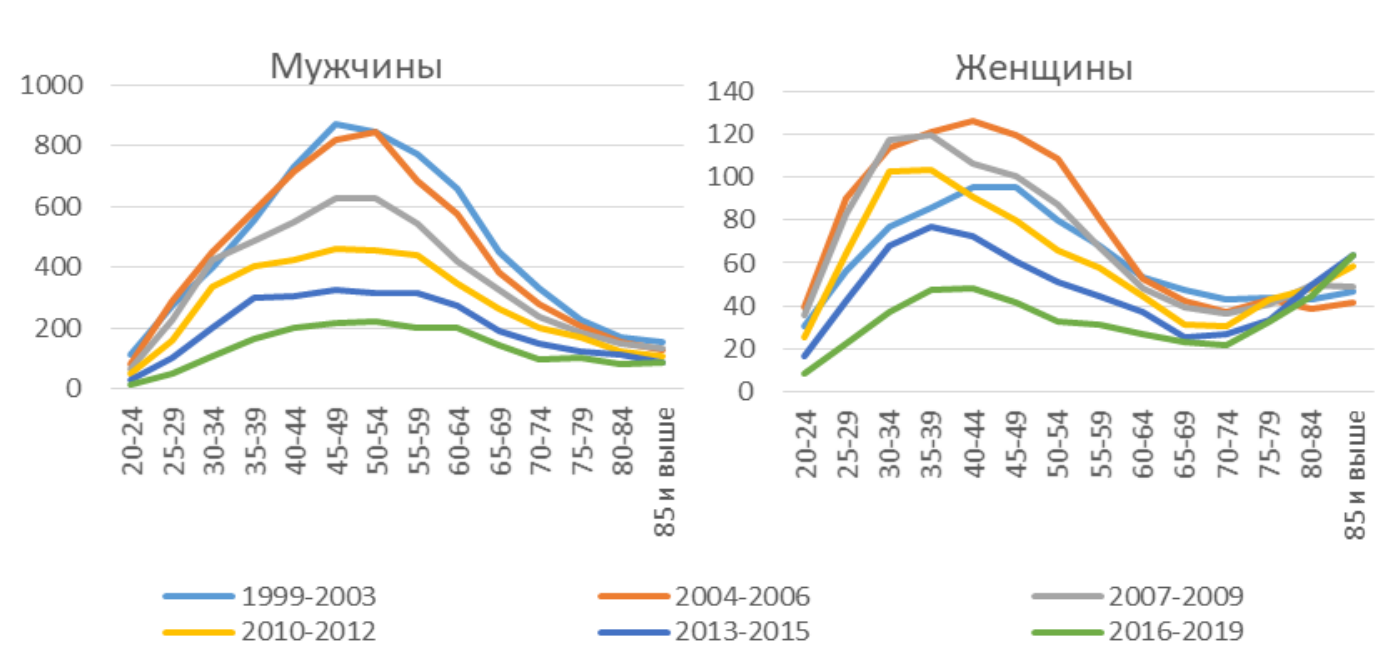

Рисунок 7. Возрастные коэффициенты смертности туберкулёза 1999-2019 гг., на 1000 тыс. чел.

Источник: Составлено автором на основе данных (Российская экономическая школа 2019).

Если в 2004-2006 гг. (когда смертность от туберкулёза была наиболее высокой и СКС составлял около 90 на 100 тыс. человек) возрастные коэффициенты смертности мужчин в 
группе от 40 до 59 лет значительно превышали смертность в остальных группах, то к настоящему времени они снизились и относительно равномерно распределились между возрастными группами от 35 до 64 лет.

На картограмме (рисунок 8) представлена типология регионов в зависимости от величины СКС мужчин. Как видно из рисунка, большая часть субъектов в северо-западной, центральной и южной части России относится к 1-му типу, т. е. в этих регионах СКС не превышает 10 на 100 тыс. человек как от ВИЧ, так и от туберкулёза. Также для центра и северо-запада характерен 2-ой тип - низкий уровень смертности от ТБ и средний уровень смертности от ВИЧ. Регионы Поволжья преимущественно относятся к 6-му типу, как и некоторые регионы Сибири: в них средний уровень смертности от ТБ и высокий от ВИЧ. Регионы Сибири преимущественно относятся к 3, 5-му и 6-му типам: в них высокий уровень смертности от ВИЧ и средний или низкий уровень смертности от ТБ. Для южных субъектов Дальнего Востока характерен 4-й тип - средний уровень смертности от ТБ и низкий от ВИЧ. Лишь в двух регионах СКС от ТБ находится на уровне выше 30 на 100 тыс. человек - это Чукотский автономный округ и Республика Тыва.

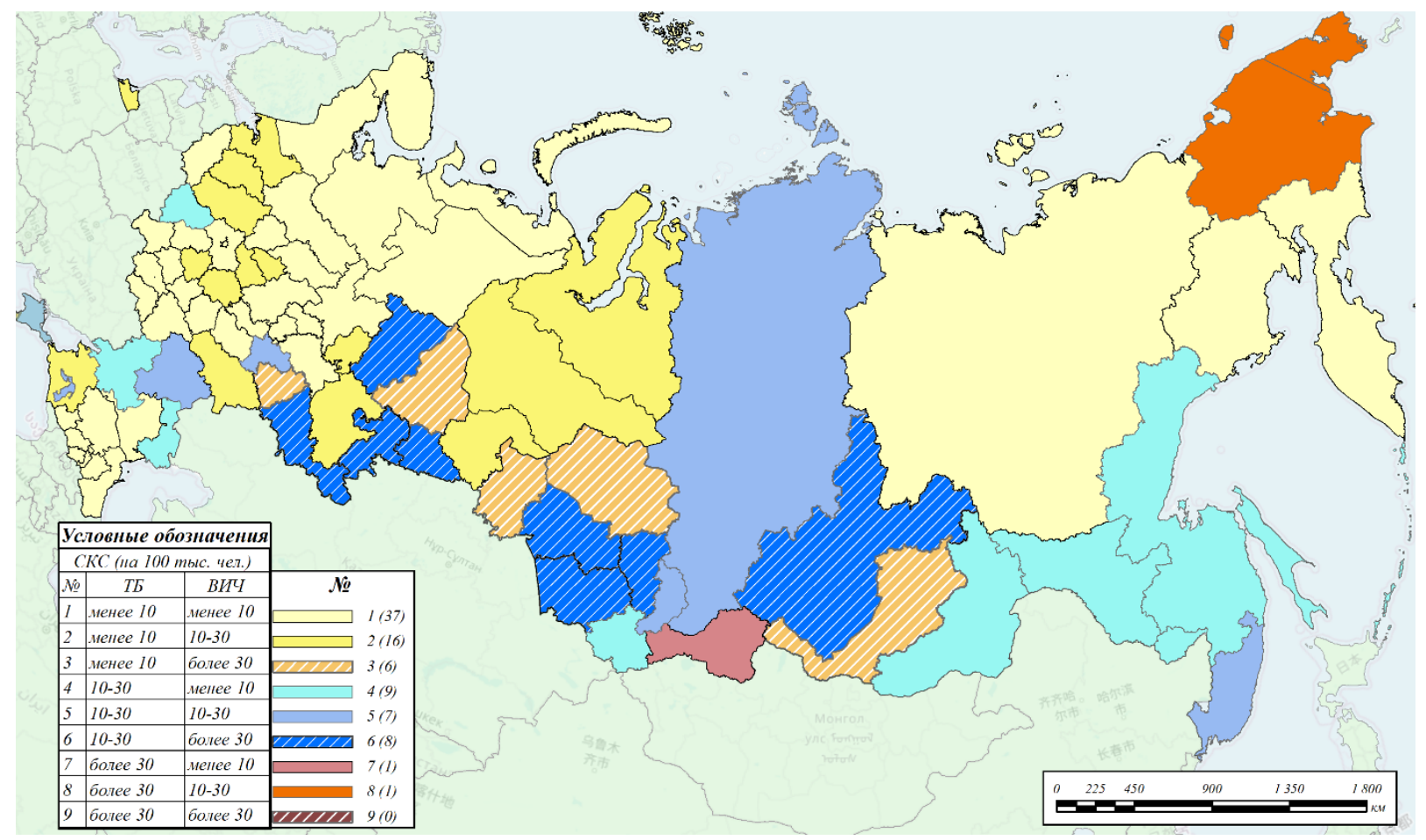

Рисунок 8. Типы регионов по уровню СКС от ВИЧ и ТБ в 2019 г., мужчины, на 100 тыс. чел.

Источник: Составлено автором на основе данных (Российская экономическая школа 2019).

Мы можем проследить, как изменилась региональная ситуация к 2019 г. (по сравнению с 1999 и 2010 г.). СКС от ТБ значительно снизился во всех субъектах (рисунок 9), но «лидеры» остаются теми же. В Республике Тыва в 2019 г. регистрируется СКС мужчин, превышающий 80 на 100 тыс. человек, это в 2 раза ниже, чем показатель 1999 г. Для сравнения, в Курганской области и Приморском крае, находящихся на 2-м и 3-м местах соответственно, этот показатель в 2019 г. составляет около 23,1 и 23,3 на 
100 тыс. человек (т. е. почти в 3 раза меньше, чем в Туве), причем у них наблюдаются быстрые темпы снижения даже по сравнению с 2018 г., чего не наблюдается в Туве.
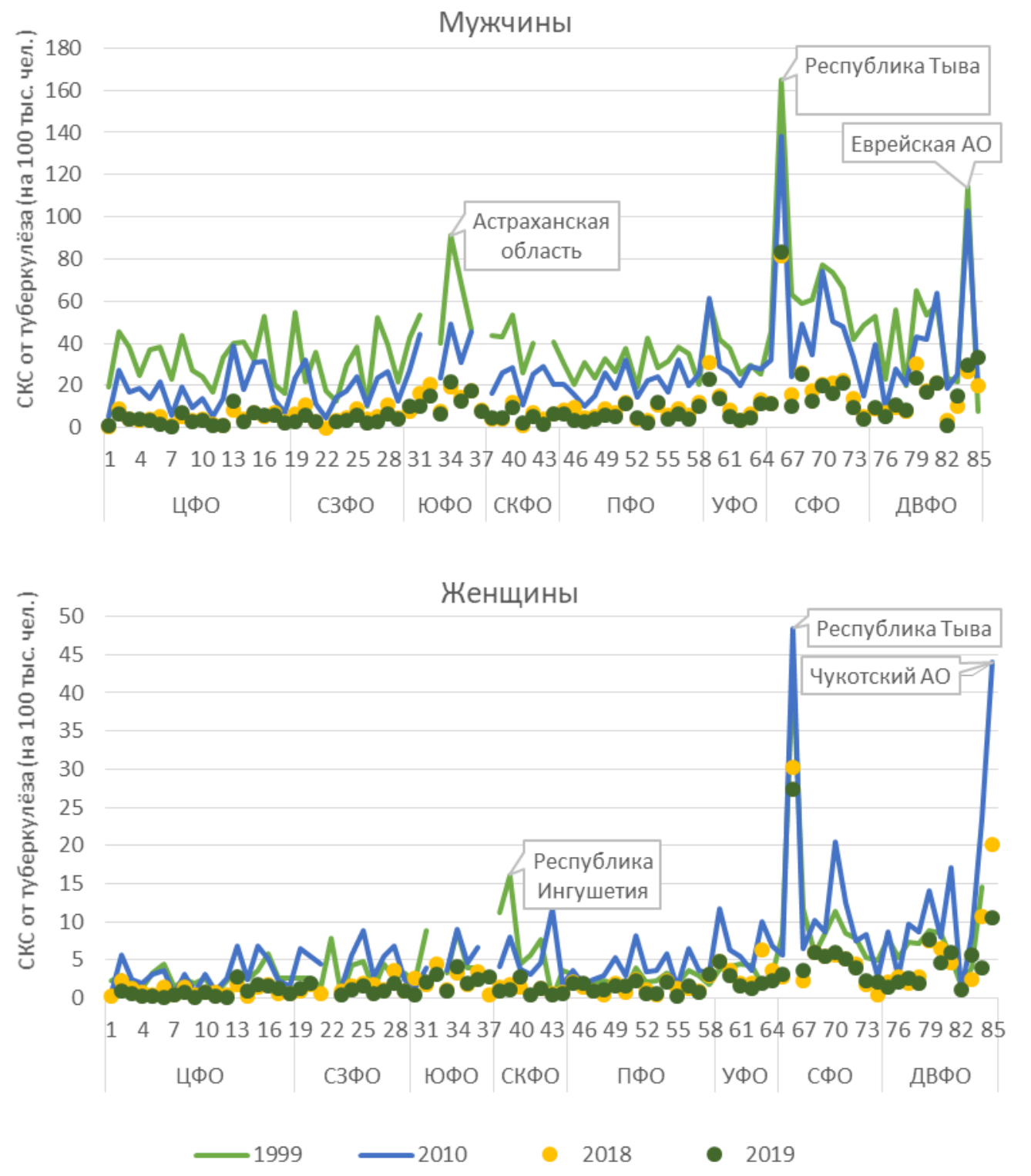

\section{Рисунок 9. Стандартизованный коэффициент смертности от туберкулёза,} на 100 тыс. чел.

Источник: Составлено автором на основе данных (Российская экономическая школа 2019).

Рисунок 10 демонстрирует, насколько схожа ситуация в мужской и женской смертности от ВИЧ-инфекции. 

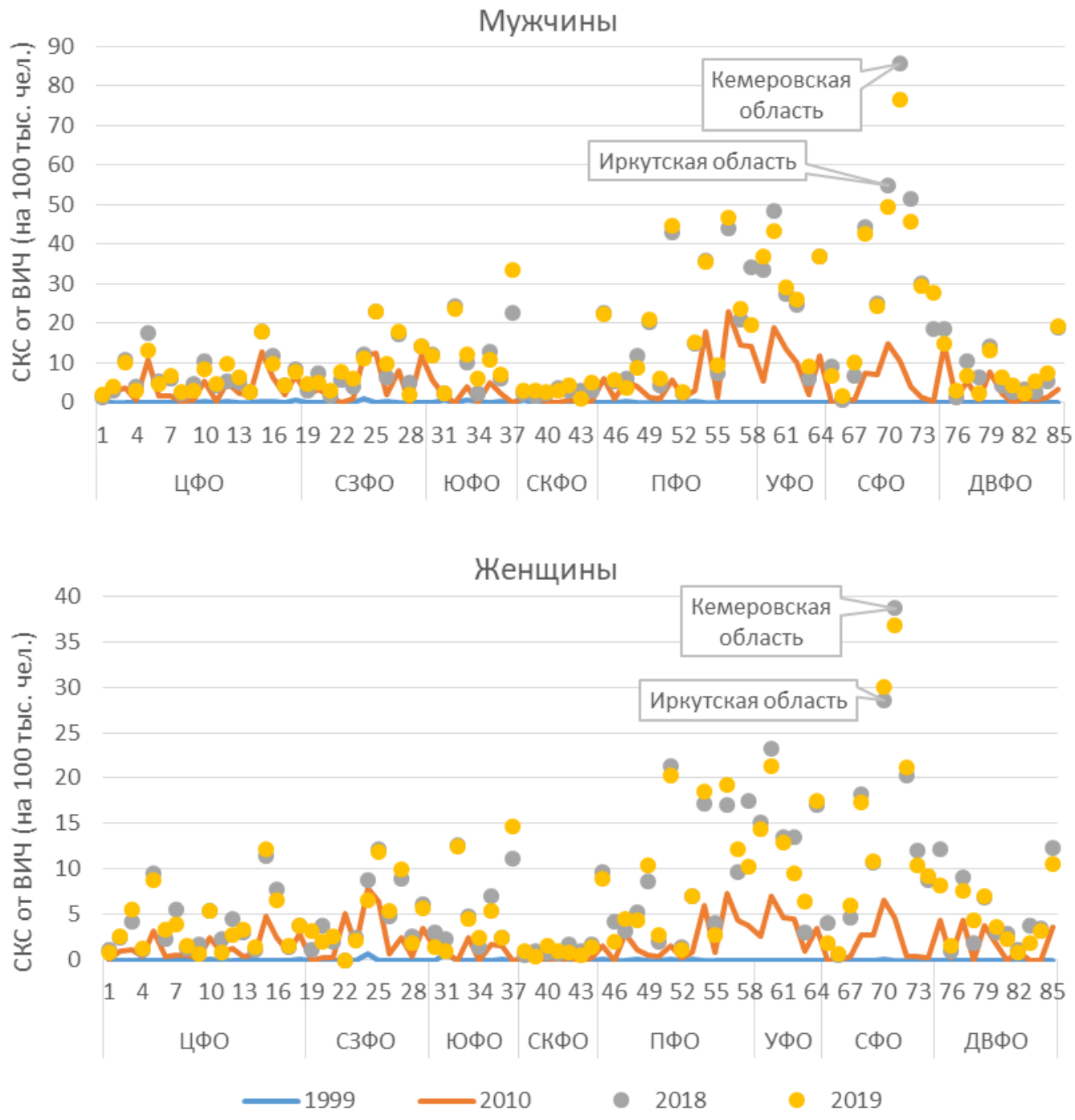

\section{Рисунок 10. Стандартизованный коэффициент смертности от ВИЧ в регионах России, на 100 тыс. чел.}

Источник: Составлено автором на основе данных (Российская экономическая школа 2019).

В смертности от ВИЧ мы наблюдаем одних и тех же «лидеров» (например, Кемеровская, Иркутская и Свердловская области) и «антилидеров» (например, все регионы СКФО) на протяжении всего временного отрезка, но важно заметить, что, если в 2010 г. лидеры по смертности находились на одном уровне, то к 2019 г. разница между ними значительно увеличилась. В некоторых регионах СКС увеличился в два раза (в Самарской области - с 23,11 до 46,7, в Ленинградской - с 12,36 до 23 на 100 тыс. человек), но в некоторых изменение было более значительным: в Пермском крае СКС увеличился в 8 раз (с 5,5 до 44,6 на 100 тыс. человек) в Кемеровской области - в 7 раз (с 10,3 до 76,6).

\section{Взаимосвязи}

Ряд специалистов отмечают, что одним из важных факторов, влияющих на смертность от ВИЧ, является наркотрафик: регионы, смертность в которых от ВИЧ была максимальной по России в 2018 г., частично пересекаются с регионами, где в 2018 г. было изъято максимальное количество наркотических средств опийной группы. Это Москва, 
Кемеровская, Свердловская, Московская, Самарская, Челябинская, Омская, Иркутская, Новосибирская и Еврейская автономная области (Линделл, Звездина, Тарасенко 2019). Данная связь смертности от ВИЧ и распространенности наркомании подтверждалась в исследовании Е.М. Андреева (Андреев, Тимонин 2017), но коэффициент корреляции Пирсона за период 2004 - 2014 гг. ни разу не превышал 0,63, а в 2014 г. был равен 0,56, поэтому об однозначной тесной связи между двумя показателями говорить не приходится. Вероятнее всего, взаимосвязь здесь возникает не столько из-за высокой летальности наркоманов, сколько из-за высокого уровня распространения инфекции благодаря наркотрафику. К тому же из данных Роспотребнадзора следует, что с каждым годом доля новых случаев среди потребителей наркотиков быстрыми темпами снижается (Покровский, Ладная, Покровская 2017; Федеральный научно-методический центр... 2019), но это никак не сказывается на показателях СКС - они непременно растут.

Другие авторы пытаются анализировать иные многочисленные социальные и экономические факторы, которые могут влиять на уровень смертности от ВИЧ, такие как уровень оказания медицинской помощи в регионе, наличие в нём профильных некоммерческих организаций, общее экономическое состояние субъекта и др. (Линделл, Звездина, Тарасенко 2019). Однако, во-первых, статистическую значимость с данными показателями подтвердить или сложно (в связи со сложностью определения индикаторов), или невозможно (в связи с отсутствием данных), а, во-вторых, такие попытки предпринимались, но из них следует, что индикаторы человеческого развития регионов (душевой валовой региональный продукт по паритету покупательной способности - ВРП по ППС, индекс доходов, ожидаемая продолжительность жизни - ОПЖ, индекс долголетия, индекс человеческого развития - ИЧР) не коррелируют со смертностью от ВИЧ (Андреев, Тимонин 2017). В своем анализе В.В. Покровский утверждает, что нет взаимосвязи между образованием, материальным достатком и уровнем распространения ВИЧ: большинство заболевающих в последние годы это молодое (30-50 лет) трудоспособное население, 87\% ВИЧ-положительных работают (Покровский, Ладная, Покровская 2017). Из исследования социально-демографического портрета ВИЧ-положительного (Покровская, Козырина, Гущина 2016) следует, что и мужчины, и женщины, посещающие центры СПИД, по социальным и демографическим характеристикам не отличаются от ВИЧ-негативных россиян такого же возраста. К тому же иногда исследователи приходят к выводу, что наибольшую распространенность имеют регионы, которые экономически развиты весьма сильно (мы действительно видим это в нашей работе: такие «лидеры» по многим показателям, как Кемеровская, Свердловская, Самарская области, Москва и СанктПетербург занимают далеко не последние места по уровню экономического развития).

Из результатов некоторых исследований следует, что число случаев смерти не зависит от среднедушевых денежных доходов населения, дохода медицинских работников, инвестиций в здравоохранение и численности населения, получающего доход ниже величины прожиточного минимума (Мехоношина и др. 2017), а из исследования А.С. Подымовой (Подымова и др. 2018) - что с увеличением ВРП на душу населения, уменьшением числа людей с доходами ниже прожиточного минимума и ростом образованности региона число новых случаев заболевания ВИЧ-инфекцией только 
увеличивается. Таким образом, найти связь между смертностью от ВИЧ и уровнем экономического неблагополучия не удается.

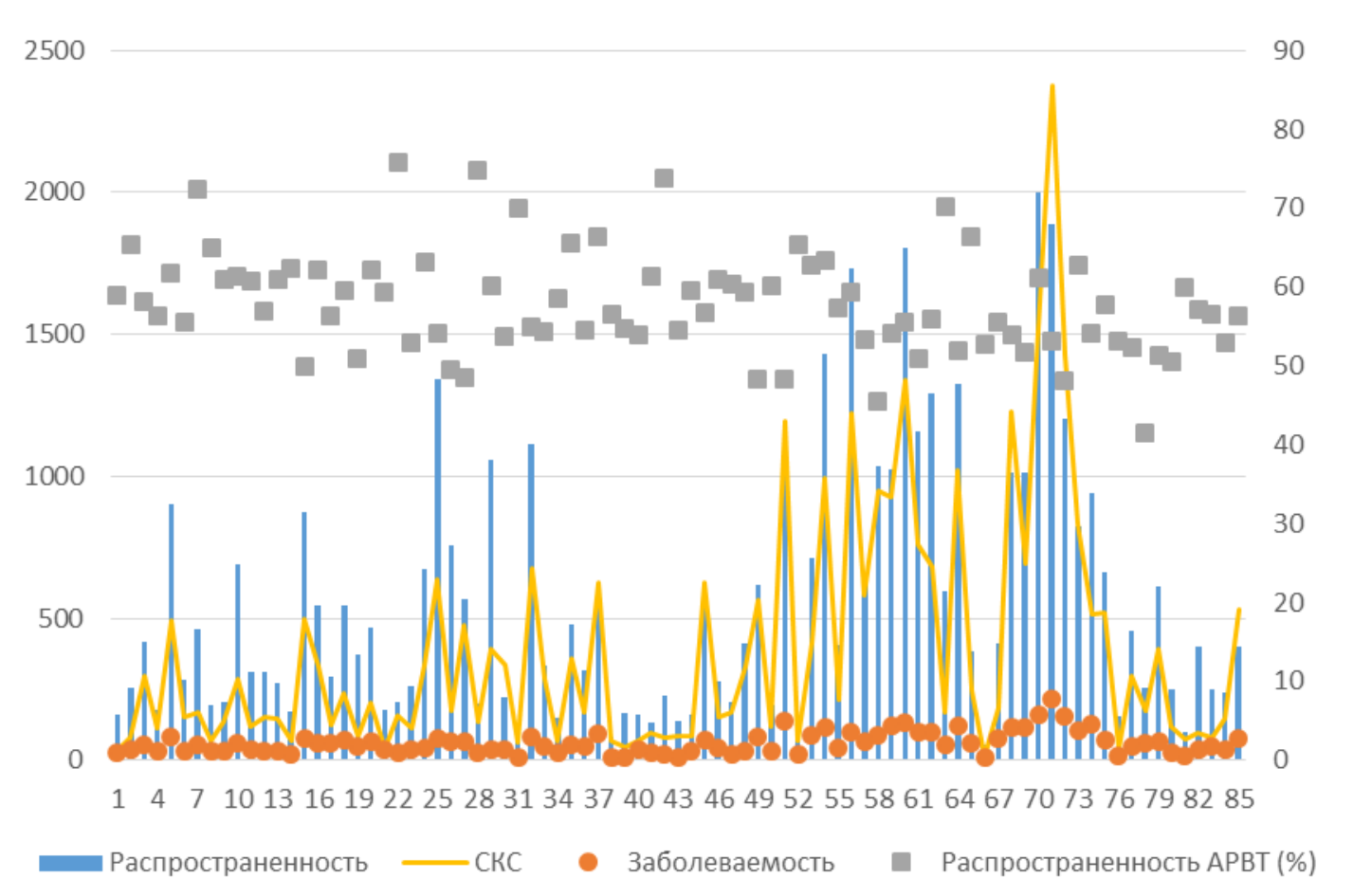

\section{Рисунок 11. Заболеваемость, распространенность и смертность от ВИЧ-инфекции за 2018 г. (на 100 тыс. чел.), распространенность АРВТ, \%}

Источник: Составлено автором на основе данных (Федеральный научно-методический иентр... 2019).

С другой стороны, мы видим очевидную взаимосвязь между смертностью и распространённостью (рисунок 11). Показатели заболеваемости и смертности от ВИЧинфекции в 2018 г., а также её распространенности на 31.12.2018 соотносимы между собой (где была выше заболеваемость, там была выше распространенность, а также выше смертность), а вот с распространенностью АРВТ никакой значительной корреляции не наблюдается.

Мы предполагаем, что отчасти это может быть связано с тем, что люди начинают получать терапию слишком поздно: в исследовании Яковлева (Яковлев, Мусатов, Савченко 2015), проведённом в СПб ГБУЗ «Клиническая инфекционная больница им. С.П. Боткина» говорится, что в подавляющем большинстве случаев $(90,4 \%)$ пациенты начинали прием АРВТ в состоянии иммунодефицита (стадия СПИД, число CD4-лимфоцитов <200 кл./мкл), а каждый третий пациент, начавший получать АРВТ, относился к группе «поздно выявленных больных».

Исследователи указывают на то, что хоть АРВТ, применяемая в клинической практике, и обеспечивает стабильную супрессию ВИЧ у разных категорий больных, но, несмотря на всю свою эффективность, функциональная недостаточность клеточного и гуморального иммунитета у больных с супрессией ВИЧ определяет тяжелое, потенциально некурабельное течение оппортунистических инфекций, особенно при их сочетании (Мусатов и др. 2017), а одной из таких инфекций и является туберкулёз. Поэтому мы можем 
сделать вывод, что одного только широкого распространения АРВТ может быть недостаточно: важно, чтобы распространение было своевременным.

Для определения тесноты связи (и направления зависимости) между заболеваемостью, распространенностью и смертностью от ВИЧ-инфекции и туберкулёза нами был выполнен корреляционный анализ посредством вычисления коэффициента ранговой корреляции Спирмена (r).

Из результатов корреляционного анализа следует, что очень тесную взаимосвязь имеют показатели стандартизованного коэффициента смертности от ВИЧ и распространенности ВИЧ как среди мужчин $(\mathrm{r}=0,92 ; \mathrm{p}<0,01)$, так и среди женщин $(\mathrm{r}=0,91$; $\mathrm{p}<0,01)$, а также сильно коррелируют показатели СКС от ВИЧ и распространенности ТБ/ВИЧ (r=0,9; $<<0,01)$, но в то же время показатели СКС от ВИЧ и показатели СКС от ТБ, хоть и взаимосвязаны, но коррелируют не так тесно $(\mathrm{r} \approx 0,3-0,4 ; \mathrm{p}<0,05)$. То же самое наблюдается и в корреляционной взаимосвязи между СКС от ТБ и распространенностью ТБ/ВИЧ (r $\approx 0,4-0,5 ; \mathrm{p}<0,05)$, что можно рассматривать как косвенное подтверждение тезиса о том, что умершие при наличии сочетания ТБ/ВИЧ чаще регистрируются как умершие от ВИЧ-инфекции, нежели умершие от туберкулёза. Очень тесная взаимосвязь обнаружена также между СКС мужчин и СКС женщин ( $\mathrm{r}=0,9 ; \mathrm{p}<0,01)$ : в регионах, где высока мужская смертность, высока и женская (и наоборот).

Смертность от туберкулёза тесно коррелирует только с его распространенностью $(\mathrm{r}=0,8 ; \mathrm{p}<0,01)$, а не с распространенностью ВИЧ-инфекции $(\mathrm{r} \approx 0,25 ; \mathrm{p}<0,05)$, соответственно, где туберкулёз наиболее распространен, там наиболее распространена и смертность от него.

Из того, что показатели распространённости и смертности по двум причинам по отдельности сильно коррелируют между собой, а в случае распространения коинфекции тесная её взаимосвязь прослеживается только с ВИЧ, мы можем предположить, что в статистику смертности от туберкулёза идут в основном ВИЧ-негативные контингенты, а больные туберкулёзом ВИЧ-позитивные попадают в категорию смертности от ВИЧ.

Распространенность ВИЧ-инфекции и распространенность туберкулёза (в его моноварианте) не показали тесной взаимосвязи (коэффициент корреляции между состоящими на учёте на 31.12.2018 составил $\mathrm{r}=0,21$; $\mathrm{p}=0,054)$, не обнаружилось тесной взаимосвязи и между заболеваемостью ВИЧ за 2018 г. и распространенностью туберкулёза $(\mathrm{r}=0,33 ; \mathrm{p}<0,05)$, а вот заболеваемость ВИЧ и его распространенность коррелируют очень сильно ( $\approx 00,9 ; \mathrm{p}<0,01)$, что говорит о высокой степени риска заболевания в регионе, где уровень распространения ВИЧ достаточно высок. Также, исходя из вышесказанного, мы можем сделать вывод, что туберкулёз и ВИЧ-инфекция как отдельные заболевания не обязательно максимально распространены в одних и тех же регионах, хоть слабая взаимосвязь между ними и имеется.

При сравнении, насколько сильно в 2018 г. были взаимосвязаны общая заболеваемость ВИЧ, заболеваемость среди ФСИН-контингентов и заболеваемость потребителей наркотиков, выяснили, что между всеми показателями наблюдается умеренная взаимосвязь $(\mathrm{r}=0,634$ и $\mathrm{r}=0,665 ; \mathrm{p}<0,01)$, что логично, учитывая, что данные 
контингенты ежегодно составляют не менее $40 \%$ в структуре новых случаев обнаружения ВИЧ. Также это может говорить о том, что регионы-лидеры по заболеваемости ВИЧ до сих пор получают значительный вклад в заболеваемость от уязвимых контингентов.

Мы определили тесноту связи между долей лиц, получающих АРВТ (от состоящих на диспансерном учёте) и смертностью как от ВИЧ, так и от туберкулёза. Выяснилось, что слабая обратная взаимосвязь между этими показателями имеется, причём теснее она между смертностью от туберкулёза ( $\mathrm{r}=-0,29$ для мужчин и $\mathrm{r}=-0,36 ; \mathrm{p}<0,01)$, чем от ВИЧ ( $\mathrm{r}=-0,22$ для мужчин и $\mathrm{r}=-0,25$ для женщин; $\mathrm{p}<0,05)$, что позволяет сделать предположение о том, что, чем большая доля ВИЧ-положительного населения региона имеет доступ к АРВТ, тем меньше в этом регионе смертность, но теснота взаимосвязей слишком незначительна и, несмотря на логичность предположения оно требует дальнейшей проверки. Вполне может оказаться, что превалирующие влияние на снижение смертности от ВИЧ-инфекции будет иметь время, которое прошло между заболеванием человека и получением им АРВТ, нежели просто уровень распространённости АРВТ в регионе.

\section{ОБСУЖДЕНИЕ РЕЗУЛЬТАТОВ}

В России имеются различные недоработки в плане статистического учёта обеих болезней, что негативно сказывается на возможности не только анализировать ситуацию, но и принимать меры, способствующие улучшению эпидемиологической ситуации. Иногда данные не позволяют точно определить, какие меры нужно принимать, поэтому важно осуществлять пересмотр действующих статистических форм и, возможно, самого подхода к борьбе с ВИЧ, так как те меры, которые принимаются сейчас, очевидно не оказывают существенного влияния на ситуацию.

Отдельным ограничением анализа эпидемической ситуации служит несовершенство статистической формы ФГСН №61 «Сведения о болезни, вызванной вирусом иммунодефицита человека» (приказ Росстата от 30.12.2015 №672). Она не отвечает современным требованиям регистрации ВИЧ и не создаёт предпосылок для корректного планирования мер по улучшению эпидемической ситуации (Нечаева 2019). Данная форма не позволяет подсчитать большинство индикаторов, заложенных в стратегию противодействия распространению ВИЧ-инфекции и в соответствующие разделы программы «Развитие здравоохранения» (ФГБУ «ЦНИИОИЗ» Минздрава... 2017а).

Согласно оценке последствий реформ в здравоохранении, сделанной О.Б. Нечаевой (ФГБУ «ЦНИИОИЗ» Минздрава... 2017а), в статистическом учёте существует довольно много проблем, относящихся прежде всего к учётной форме ФГСН №61:

- нельзя получить информацию о числе пациентов с ВИЧ-инфекцией, умерших при наличии туберкулеза;

- неизвестен иммунологический статус ВИЧ-позитивных пациентов, без этого нельзя планировать потребность в антиретровирусной терапии (АРВТ);

- нет информации о путях передачи ВИЧ, что важно для прогнозирования вариантов развития эпидемического процесса при ВИЧ и при ТБ;

- $\quad$ нет полных данных о том, как протекает/протекало лечение ВИЧ-инфицированных; 
- неизвестно, у какой доли людей есть лекарственная устойчивость к антиретровирусным препаратам;

- отсутствуют данные обследований групп высокого риска, которые Россия должна предоставлять в ВОЗ (из-за этого много лет российских показателей нет в базе данных ВОЗ).

Также форма ФГСН №61 не позволяет получить полные сведения о впервые инфицированных ВИЧ в стадии бессимптомного течения, что может приводить к некорректным сопоставлениям российских и зарубежных данных (ФГБУ «ЦНИИОИЗ» Минздрава... 2017a).

Активно развивающаяся эпидемия ВИЧ-инфекции на сегодняшний день является полноценной социальной угрозой российскому обществу. В то же время, несмотря на снижение заболеваемости, распространённости и смертности от туберкулёза, который является основной причиной смерти ВИЧ-положительных контингентов и обладает одними из самых высоких показателей летальности, ситуация с ним остаётся неоднозначной (во многом из-за вышеназванных проблем статистического учёта).

Региональные тренды развития эпидемической ситуации различаются между собой во всех рассматриваемых аспектах. Существуют регионы, где ВИЧ уже распространился выше уровня в 1500 на 100 тыс. человек (Кемеровская, Иркутская, Свердловская, Самарская области), но существуют и те, где эпидемия ещё не начала набирать обороты (Республики Тыва, Хакасия, Алтай), хотя в них, в свою очередь, высок уровень распространения туберкулёза. Поэтому нам представляется важным понимание региональной специфики, что позволит принимать «тормозящие» меры в одних регионах и стараться не допустить развития эпидемии в тех регионах, где она пока находится в зачатке.

Сама по себе динамика развития и заболеваемости, и распространённости, и смертности от инфекций неоднородна, регионы буквально ежегодно сменяют друг друга на «лидирующих» позициях, что также добавляет сложности в выделении ключевых факторов, влияющих на данные показатели.

Обе болезни можно назвать «мужскими» и «молодыми»: наиболее часто встречающиеся в группах риска контингенты - это мужчины в возрасте 20-50 лет, они больше заболевают и больше умирают, причём половозрастные характеристики, в отличие от различий в масштабах, схожи во всех субъектах.

Анализ взаимосвязи распространённости и смертности показал, что на сегодняшний момент однозначно определить, от чего конкретно зависит уровень смертности от ВИЧинфекции, затруднительно, но он точно зависит от степени распространения ВИЧ на территории субъекта. Не удалось обнаружить достаточно достоверной взаимосвязи между распространённостью АРВТ и смертностью от ВИЧ, что может служить косвенным доказательством не только недостаточного распространения АРВТ (в России на 2018 г. менее половины живущих с ВИЧ получали терапию, но положительная динамика наблюдается), но и недостаточной её эффективности (например, из-за слишком позднего выявления ВИЧ, начала лечения или слабой приверженности терапии). Также несмотря на то, что в нашем обществе принято считать контингентами, подверженными таким 
болезням, как ВИЧ и туберкулёз, лиц, демонстрирующих негативное девиантное поведение, анализ заболеваемости этими инфекциями показывает, что они уже не являются единственными контингентами и болезни выходят за пределы традиционно признаваемых уязвимых групп.

\section{ЗАКЛЮЧЕНИЕ}

На формирование статистики смертности от ВИЧ и туберкулёза влияют специалисты, заполняющие медицинские свидетельства о смерти (патологоанатомы, судмедэксперты), но понять, чем они руководствуются при установлении причины смерти в случае сочетанной инфекции, не всегда представляется возможным. При наличии у пациента обеих инфекций в статистику с очень высокой долей вероятности пойдёт именно ВИЧ, а не туберкулёз. Вероятно, потому что ВИЧ считается заболеванием смертельным, а туберкулёз таким не считается. К тому же ВИЧ сегодня рассматривается как более социально значимое заболевание, нежели туберкулёз. Нам же кажется, что понимание того, какая болезнь предшествует другой, очень важно, тем более что есть морфологические критерии этого различия. Важно учитывать наличие туберкулёза в случае коморбидности и видеть его в статистике. Исходя из вышесказанного, мы считаем необходимым серьезно улучшить статистический учёт в России.

Настоящее исследование в очередной раз подтверждает, что в наши дни заболеваемость туберкулёзом - это в значительной степени удел ВИЧ-позитивных контингентов, а смерть от ВИЧ в большинстве случаев наступает как следствие прогрессирования туберкулёза, поэтому нам представляется разумным объединение усилий специалистов, противодействующих ВИЧ и ТБ, что допускает возможность создания единых ВИЧ-ТБ диспансеров.

\section{БЛАГОДАРНОСТИ}

Автор выражает благодарность Т.Л. Харьковой и С.А. Тимонину за ценные советы и помощь в подготовке данной статьи.

\section{ЛИТЕРАТУРА}

Андреев Е.М., Тимонин С.А. (2017). Рост смертности от ВИЧ-инфекции в России в 20002015 годах (анализ данных демографической статистики). Доклад, представленный на XVIII Апрельской международной научной конференции по проблемам развития экономики и общества. Москва, Россия.

Линделл Д., Звездина П., Тарасенко Е. (2019). В России сменилась тройка регионовлидеров по смертности от ВИЧ. URL:

https://www.rbc.ru/society/11/03/2019/5c6c0ae49a79477703d915b7

Маньшина А.В., Тоскин И., Хальфин Р.А., Мадьянова В.В., Гетахун Х., Блондил К. (2017). Эпидемиология туберкулеза, сочетанного с ВИЧ-инфекцией, в странах Восточной Европы и в Российской Федерации в 2004-2014 гг. (обзор литературы). 
Профилактическая медищина, 20(1), 50-56. DOI:

https://DOI.org/10.17116/profmed201720150-56

Мехоношина Н.В., Гудилина Н.А., Ростова Н.Б., Толстоброва Н.А., Файзрахманов Р.А. (2017). Анализ социально-экономических показателей, заболеваемости и смертности ВИЧ-инфицированных пациентов в РФ. ВИЧ-инфекция и иммуносупрессии, 9(3), 103 112. DOI: https://DOI.org/10.22328/2077-9828-2017-9-3-103-112

Михайлова Ю.В., Нечаева О.Б., Шикина И.Б., Сорокин В.Н. (2018). Влияние миграционных факторов на эпидемическую ситуацию по туберкулёзу и ВИЧинфекции в России. Социальные аспекты здоровья населения, 62(4). DOI: https://DOI.org/10.21045/2071-5021-2018-62-4-4

Мусатов В.Б., Яковлев А.А., Савченко М.А., Соколова О.И. (2017). Летальные исходы у ВИЧ-инфицированных больных, имеющих неопределяемую вирусную нагрузку на фоне антиретровирусной терапии. Инфекционные болезни: Новости. Мнения. Обучение, 4(21), 67-71. DOI: https://DOI.org/10.24411/2305-3496-2017-00071

Нечаева О.Б. (2013). Туберкулез в Российской Федерации: заболеваемость и смертность. Медицинский алфавит, 4(24), 7-12.

Нечаева О.Б. (2017а). Мониторинг туберкулеза и ВИЧ-инфекции в Российской Федерации. Медицинский алфавит, 3(30), 24-33.

Нечаева О.Б. (2017b). Эпидемическая ситуация по туберкулезу среди лиц с ВИЧинфекцией в Российской Федерации. Туберкулёз и болезни лёгких, 95(3), 13-19. DOI: https://DOI.org/10.21292/2075-1230-2017-95-3-13-19

Нечаева О.Б. (2019). Социально значимые инфекционные заболевания, представляющие биологическую угрозу населению России. Туберкулёз и болезни легких, 97(11), 7-17. DOI: https://DOI.org/10.21292/2075-1230-2019-97-11-7-17

Нечаева О.Б., Подымова А.С. (2018). Влияние ВИЧ-инфекции на демографическую ситуацию в России. Медицинский альянс, 1, 6-15.

Подымова А.С., Тургель И.Д., Кузнецов П.Д., Чукавина К.В. (2018). Выявление социально-экономических факторов, определяющих распространение ВИЧ-инфекции в регионах России. Вестник УрФУ. Серия экономика и управление, 17(2), 242-262. DOI: https://DOI.org/10.15826/vestnik.2018.17.2.011.

Покровская А.В., Козырина Н.В., Гущина Ю.Ш. (2016). Социально-демографический портрет пациента, живущего с ВИЧ и посещающего центры СПИД в России. Терапевтический архив, 88(11), 12-16. https://DOI.org/10.17116/terarkh2016881112-16

Покровский В.В., Ладная Н.Н., Покровская А.В. (2017). ВИЧ/СПИД сокращает число россиян и продолжительность их жизни. Демографическое обозрение, 4(1), 65-82. DOI: https://doi.org/10.17323/demreview.v4i1.6988

Российская экономическая школа (2019). Российская база данных по рождаемости и смертности. URL: http://demogr.nes.ru/index.php/ru/demogr_indicat/data

Стерликов С.А. (Ред.) (2018). ТБ/ВИЧ в Российской Федерации. Эпидемиология, особенности клинических проявлений и результать лечения. М.: РИО ЦНИИОИЗ. URL: http://mednet.ru/images/stories/files/CMT/mono2018.pdf

ФГБУ «ЦНИИОИЗ» Минздрава России (2017а). Показатели по ВИЧ в Российской Федерации 2008-2017. URL: https:/цнииоиз.pф/images/stories/files/Vich-_2008-2017.pdf 
ФГБУ «ЦНИИОИЗ» Минздрава России (2017b). Эпидемическая ситуаџия по ВИЧинфекции в России. URL: https://mednet.ru/images/stories/files/miac/2017_vich.pdf

ФГБУ «ЦНИИОИЗ» Минздрава России (2018). Эпидемическая ситуация по туберкулёзу в России. URL: https://mednet.ru/images/materials/CMT/2018_god_tuberkulez_epidsituaciya.pdf

ФГБУ «ЦНИИОИЗ» Минздрава России (2019). Эпидемическая ситуащия по туберкулёзу в России. URL: https://mednet.ru/images/materials/CMT/tuberkulez-2019.pdf

Федеральный научно-методический центр по профилактике и борьбе со СПИДом (2019). Бюллетень №44. ВИЧ-инфекция. URL: http://www.hivrussia.info/wpcontent/uploads/2020/01/Byulleten-44-VICH-infektsiya-2019-g..pdf

Федеральный научно-методический центр по профилактике и борьбе со СПИДом (2020а). ВИЧ-инфекиия в Российской Федераџии на 30 июля 2020 г. URL:

http://www.hivrussia.info/wp-content/uploads/2019/10/VICH-infektsiya-v-RossijskojFederatsii-v-pervom-polugodii-2019-g..pdf

Федеральный научно-методический центр по профилактике и борьбе со СПИДом (2020b). ВИЧ-инфекиия в Российской Федерациии на 30 сентября 2020 г. URL: http://www.hivrussia.info/wp-content/uploads/2020/11/Spravka-VICH-v-Rossii-9-mes2020.pdf

Цыбикова Э.Б., Владимиров А.В. (2015). Смертность от туберкулеза и ВИЧ-инфекции в разных возрастно-половых группах населения в России в начале XXI века. Здравоохранение Российской Федеращии, 5, 4-9.

Цыбикова Э.Б., Пунга В.В., Русакова Л.И. (2018). Туберкулез, сочетанный с ВИЧинфекцией в России: статистика и взаимосвязи. Туберкулез и болезни легких, 96(12), 917. DOI: https://DOI.org/10.21292/2075-1230-2018-96-12-9-17

Яковлев А.А., Мусатов В.Б., Савченко М.А. (2015). Причины летальных исходов у ВИЧинфицированных пациентов, получающих антиретровирусную терапию. ВИЧинфекция и иммуносупрессии, 7(1), 84-89. DOI: https://doi.org/10.22328/2077-9828-20157-1-84-89

World Health Organization (2019). Global tuberculosis report. URL: https://apps.who.int/iris/bitstream/handle/10665/329368/9789241565714-eng.pdf?ua=1

Pokrovskiy V. (2014). HIV epidemic in Russia and neighbouring countries. Journal of the International AIDS Society, 17, 19502. DOI: https://DOI.org/10.7448/IAS.17.4.19502 


\section{ПРИЛОЖЕНИЯ}

Таблица. Номера субъектов

\begin{tabular}{|c|c|c|c|c|c|c|c|c|}
\hline & 1 & Белгородская обл. & & 30 & Р. Адыгея & & 59 & Курганская обл. \\
\hline & 2 & Брянская обл. & & 31 & Р. Калмыкия & & 60 & \\
\hline & 3 & Владимирская обл. & & 32 & Республика Крым & 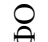 & 61 & Тюменская обл. \\
\hline & 4 & Воронежская обл. & $\stackrel{\theta}{\theta}$ & 33 & Краснодарский край & $\dot{\lambda}$ & 62 & Х.-Мансийский АО \\
\hline & 5 & Ивановская обл. & & 34 & Астраханская обл. & & 63 & Ямало-Ненецкий АО \\
\hline & 6 & Калужская обл. & & 35 & Волгоградская обл. & & 64 & Челябинская обл. \\
\hline & 7 & Костромская обл. & & 36 & Ростовская обл. & & 65 & Р. Алтай \\
\hline & 8 & Курская обл. & & 37 & Севастополь & & 66 & Р. Тыва \\
\hline 0 & 9 & Липецкая обл. & & 38 & Р. Дагестан & & 67 & Р. Хакасия \\
\hline 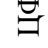 & 10 & Московская обл. & & 39 & Р. Ингушетия & & 68 & Алтайский край \\
\hline & 11 & Орловская обл. & 0 & 40 & Каб.-Балкарская Р. & ○ & 69 & Красноярский край \\
\hline & 12 & Рязанская обл. & $\underset{y}{\theta}$ & 41 & Кар.-Черкесская Р. & U & 70 & Иркутская обл. \\
\hline & 13 & Смоленская обл. & & 42 & Р. Сев.Осетия-Алания & & 71 & Кемеровская обл. \\
\hline & 14 & Тамбовская обл. & & 43 & Чеченская Р. & & 72 & Новосибирская обл. \\
\hline & 15 & Тверская обл. & & 44 & Ставропольский край & & 73 & Омская обл. \\
\hline & 16 & Тульская обл. & & 45 & Р. Башкортостан & & 74 & Томская обл. \\
\hline & 17 & Ярославская обл. & & 46 & Р. Марий Эл & & 75 & Р. Бурятия \\
\hline & 18 & Москва & & 47 & Р. Мордовия & & 76 & Р. Саха (Якутия) \\
\hline & 19 & Р. Карелия & & 48 & Р. Татарстан & & 77 & Забайкальский край \\
\hline & 20 & Р. Коми & & 49 & Удмуртская Р. & & 78 & Камчатский край \\
\hline & 21 & Архангельская обл. & & 50 & Чувашская Р. & O & 79 & Приморский край \\
\hline & 22 & Ненецкий АО & 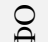 & 51 & Пермский край & $\theta$ & 80 & Хабаровский край \\
\hline 0 & 23 & Вологодская обл. & $\theta$ & 52 & Кировская обл. & & 81 & Амурская обл. \\
\hline $\bar{\theta}$ & 24 & Калининградская обл. & & 53 & Нижегородская обл. & & 82 & Магаданская обл. \\
\hline & 25 & Ленинградская обл. & & 54 & Оренбургская обл. & & 83 & Сахалинская обл. \\
\hline & 26 & Мурманская обл. & & 55 & Пензенская обл. & & 84 & Еврейская Авт.обл. \\
\hline & 27 & Новгородская обл. & & 56 & Самарская обл. & & 85 & Чукотский АО \\
\hline & 28 & Псковская обл. & & 57 & Саратовская обл. & & & \\
\hline & 29 & Санкт-Петербург & & 58 & Ульяновская обл. & & & \\
\hline
\end{tabular}

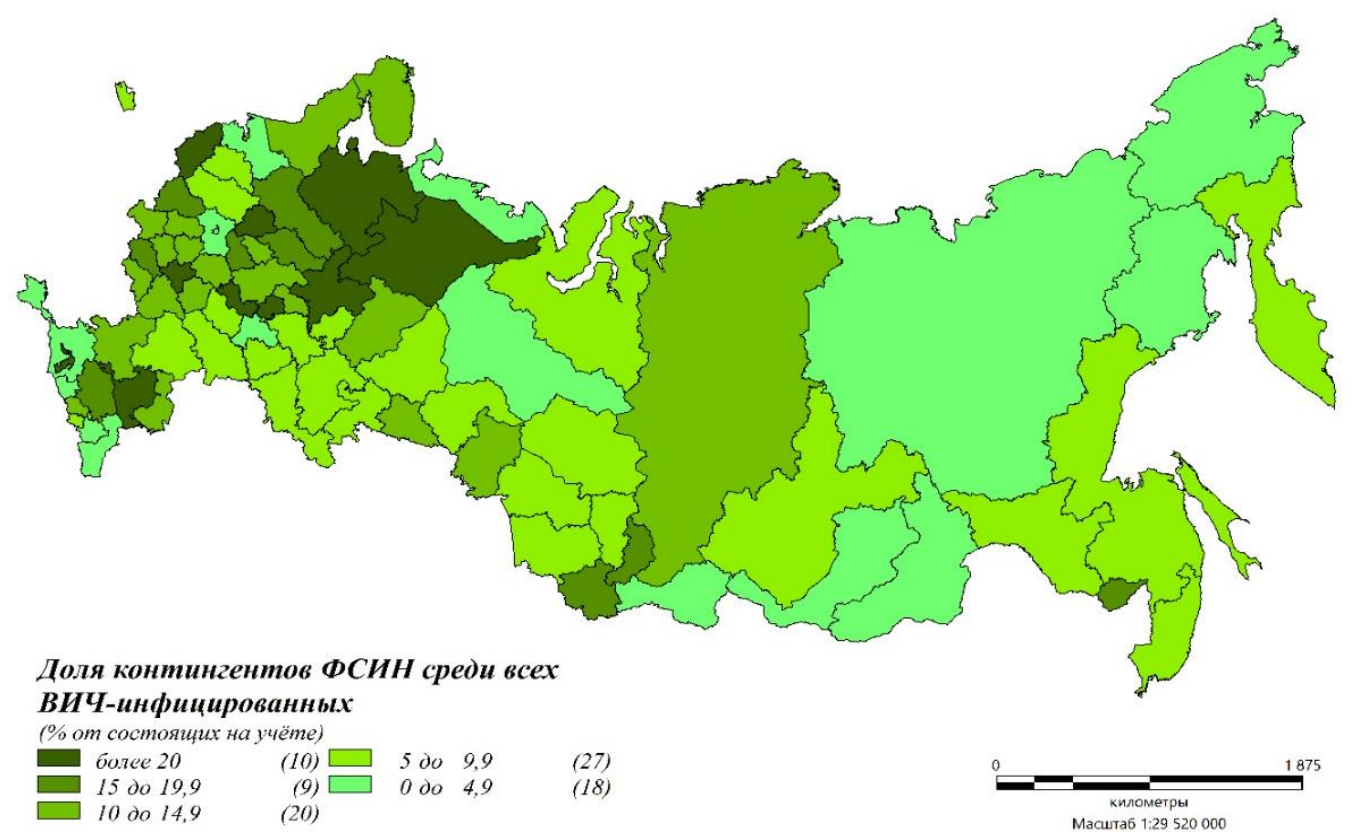

Рисунок. Доля контингентов ФСИН среди ВИЧ-инфицированных на 31.12.2018, \%

Источник: Составлено автором по (Федеральный научно-методический иентр ... 2019). 


\title{
TRENDS IN MORBIDITY, PREVALENCE AND MORTALITY FROM HIV INFECTION AND TUBERCULOSIS IN THE REGIONS OF RUSSIA IN THE XXI CENTURY
}

\author{
ALEXEY ASTRELIN
}

\begin{abstract}
According to official data from Rospotrebnadzor, more than 1 million people with HIV infection (HIV) live in Russia, while the number of both new infections and deaths has been continuously increasing over the past two decades. According to the same data, in 50\% of registered patients HIV infection is combined with tuberculosis (TB), and in more than half of those who died from HIV there was a clinical picture of progressive tuberculosis.
\end{abstract}

\begin{abstract}
This paper presents the results of a spatial analysis of the epidemiological situation with HIV infection and tuberculosis, including an attempt to determine the relationship between the development of the HIV and tuberculosis epidemic at the regional level. Regional trends differ among themselves in most of the positions considered: the dynamics of the incidence, prevalence and mortality from these infections is heterogeneous, and the regions literally replace each other in the "leading" positions every year, which adds complexity to the identification of the key factors affecting these indicators. Macro-level analysis of the relationship between the prevalence of and mortality from HIV infection and tuberculosis showed that while it is impossible to unequivocally determine what exactly the HIV mortality rate depends on, it definitely depends on the degree of HIV prevalence in the territory of the subject. At the same time, it was not possible to find a sufficiently reliable relationship between the prevalence of antiretroviral therapy (ART) and mortality from $H I V$, which can serve as indirect evidence not only of the insufficient spread of ART (in Russia in 2019, only half of HIV-positive patients received therapy), but also of its insufficient effectiveness, for example, due to too late detection of HIV or initiation of therapy.
\end{abstract}

Key words: HIV, tuberculosis, HIV-TB, coinfection, incidence, prevalence, mortality.

AleXey Astrelin (amastrelin@edu.hse.ru), National Research University Higher School of Economics, RUSSIA.

DATE RECEIVED : SEPTEMBER 2020.

\section{REFERENCES}

Andreev E.M., Timonin S.A. (2017). Rost smertnosti ot VICh-infektsii v Rossii v 2000-2015 godakh (analiz dannykh demograficheskoy statistiki) [Growth in mortality from HIV infection in Russia in 2000-2015 (analysis of demographic statistics)]. Report presented at the XVIII April International Scientific Conference on the Development of Economy and Society. Moscow, Russia. (In Russ.).

Lindell D., Zvezdina P., Tarasenko E. (2019). V Rossii smenilas' troyka regionov-liderov po smertnosti ot VICh [Three leading regions in HIV mortality have changed in Russia]. (In Russ.). URL: https://www.rbc.ru/society/11/03/2019/5c6c0ae49a79477703d915b7

Manshina A.V., Toskin I., Khal'fin R.A., Mad'yanova V.V., Getakhun Kh., Blondil K. (2017). Epidemiology of HIV-associated tuberculosis in Eastern European countries and the Russian Federation in 2004-2014: A review of literature. Profilakticheskaya meditsina [Preventive Medicine], 20(1), 50-56. (In Russ.). DOI: 10.17116/profmed201720150-56 
Mekhonoshina N.V., Gudilina N.A., Rostova N.B., Tolstobrova N.A., Faizrakhmanov R.A. An analysis of socioeconomic parameters related to HIV incidence and HIV-related mortality in the Russian Federation. HIV Infection and Immunosuppressive Disorders, 9(3), 103-112. (In Russ.). DOI:10.22328/2077-9828-2017-9-3-103-112

Mikhaylova Yu.V., Nechaeva O.B., Shikina I.B., Sorokin V.N. (2018). Impact of migration factor on TB and HIV epidemic situation in Russia. Sotsial'nyye aspekty zdorov'ya naseleniya [Social aspects of public health], 62(4). (In Russ.). DOI: 10.21045/2071-50212018-62-4-4

Musatov V.B., Yakovlev A.A., Savchenko M.A., Sokolova O.I. (2017). Lethal outcomes in HIV positive patients with undetectable viral load on antiretroviral therapy. Infectious Diseases: News, Opinions, Training, 4(21), 67-71. (In Russ.) .DOI: 10.24411/2305-3496-2017-00071

Nechaeva O.B. (2013). Tuberkulez v Rossiyskoy Federatsii: zabolevayemost' i smertnost' [Tuberculosis in the Russian Federation: morbidity and mortality]. Medical alphabet, 4(24), 7-12. (In Russ.).

Nechaeva O.B. (2017a). Monitoring of tuberculosis and HIV-infection in Russian Federation. Medical alphabet, 3(30), 24-33. (In Russ.).

Nechaeva O.B. (2017b). Tuberculosis epidemic situation among HIV positive people in the Russian Federation. Tuberculosis and Lung Diseases, 95(3), 13-19. (In Russ.). DOI: 10.21292/2075-1230-2017-95-3-13-19

Nechaeva O.B. (2019). Socially important infectious diseases posing a biological threat to the population of Russia. Tuberculosis and Lung Diseases, 97(11), 7-17. (In Russ.). DOI: https://DOI.org/10.21292/2075-1230-2019-97-11-7-17

Nechaeva O.B., Podymova A.S. (2018). Impact of HIV infection on demographic situation in Russia. Medical Alliance, 1, 6-15. (In Russ.).

Podymova A.S., Turgel I.D., Kuznetsov P.D., Chukavina K.V. (2018). Socio-Economic factors determining the dissemination of HIV Infection in the Russian Regions. Bulletin of Ural Federal University. Series Economics and Management, 17(2), 242-262. (In Russ.). DOI: 10.15826/vestnik.2018.17.2.011

Pokrovskaya A.V., Kozyrina N.V., Gushchina Yu.Sh. (2016). The sociodemographic portrait of a patient living with HIV and visiting AIDS centers in Russia. Therapeutic archive, 88(11), 12-16. (In Russ.). https://DOI.org/10.17116/terarkh2016881112-16

Pokrovskiy V.V., Ladnaya N.N., Pokrovskaya A.V. (2017). VICh/SPID sokrashchayet chislo rossiyan i prodolzhitel'nost' ikh zhizni [HIV/AIDS reduces the number of russians and their life expectancy]. Demographic Review, 4(1), 65-82. (In Russ.). DOI: https://doi.org/10.17323/demreview.v4i1.6988

Rossiyskaya ekonomicheskaya shkola [New Economic School] (2019). Rossiyskaya baza dannykh po rozhdayemosti i smertnosti [Russian database on fertility and mortality]. URL: http://demogr.nes.ru/index.php/ru/demogr_indicat/data (In Russ.).

Sterlikov S.A. (Ed.) (2018). TB/VICh v Rossiyskoy Federatsii. Epidemiologiya, osobennosti klinicheskikh proyavleniy i rezul'taty lecheniya [TB/HIV in the Russian Federation. Epidemiology, features of clinical manifestations and treatment results]. M.: RIO TsNIIOIZ. URL: http://mednet.ru/images/stories/files/CMT/mono2018.pdf (In Russ.).

FGBU «TsNIIOIZ» Minzdrava Rossii [Federal State Budgetary Institution "Central Research Institute of Healthcare Organization and Informatization" of the Ministry of Health of the Russian Federation] (2017a). Pokazateli po VICh v Rossiyskoy Federatsii 2008-2017 [The 
prevalence of HIV in the Russian Federation, 2008-2017]. URL:

https://tsniioiz.rf/images/stories/files/Vich-_2008-2017.pdf (In Russ.).

FGBU «TsNIIOIZ» Minzdrava Rossii [Federal State Budgetary Institution "Central Research Institute of Healthcare Organization and Informatization" of the Ministry of Health of the Russian Federation] (2017b). Epidemicheskaya situatsiya po VICh-infektsii v Rossii [The epidemic situation on HIV-infection in Russia]. URL:

https://mednet.ru/images/stories/files/miac/2017_vich.pdf (In Russ.).

FGBU «TsNIIOIZ» Minzdrava Rossii [Federal State Budgetary Institution "Central Research Institute of Healthcare Organization and Informatization" of the Ministry of Health of the Russian Federation] (2018). Epidemicheskaya situatsiya po tuberkulezu v Rossii [The epidemic situation of tuberculosis in Russia]. URL:

https://mednet.ru/images/materials/CMT/2018_god_tuberkulez_epidsituaciya.pdf (In Russ.).

FGBU «TsNIIOIZ» Minzdrava Rossii [Federal State Budgetary Institution "Central Research Institute of Healthcare Organization and Informatization" of the Ministry of Health of the Russian Federation] (2019). Epidemicheskaya situatsiya po tuberkulezu v Rossii [The epidemic situation of tuberculosis in Russia]. URL:

https://mednet.ru/images/materials/CMT/tuberkulez-2019.pdf (In Russ.).

Federalnyy nauchno-metodicheskiy tsentr po profilaktike i bor'be so SPIDom [Federal Scientific and Methodological Center for the Prevention and Control of AIDS] (2019). Byulleten №44. VICh-infektsiya [Newsletter №44. HIV infection]. URL: http://www.hivrussia.info/wpcontent/uploads/2020/01/Byulleten-44-VICH-infektsiya-2019-g..pdf (In Russ.).

Federalnyy nauchno-metodicheskiy tsentr po profilaktike i bor'be so SPIDom [Federal Scientific and Methodological Center for the Prevention and Control of AIDS] (2020a). VIChinfektsiya $v$ Rossiyskoy Federatsii na 30 iyulya $2020 \mathrm{~g}$. [HIV infection in the Russian Federation as of July 30, 2020]. URL: http://www.hivrussia.info/wpcontent/uploads/2019/10/VICH-infektsiya-v-Rossijskoj-Federatsii-v-pervom-polugodii2019-g..pdf (In Russ.).

Federalnyy nauchno-metodicheskiy tsentr po profilaktike i bor'be so SPIDom [Federal Scientific and Methodological Center for the Prevention and Control of AIDS] (2020b). VIChinfektsiya $v$ Rossiyskoy Federatsii na 30 sentyabrya $2020 \mathrm{~g}$. [HIV infection in the Russian Federation as of September 30, 2020]. URL: http://www.hivrussia.info/wpcontent/uploads/2020/11/Spravka-VICH-v-Rossii-9-mes-2020.pdf (In Russ.).

Tsybikova E.B., Vladimirov A.V. (2015). The mortality of tuberculosis and hiv-infection in various age gender groups of population in Russia in the beginning of xxi century.

Zdravookhraneniye Rossiyskoy Federatsii [Healthcare of the Russian Federation], 5, 4-9. (In Russ.).

Tsybikova E.B., Punga V.V., Rusakova L.I. (2018). Tuberculosis with concurrent HIV infection in Russia: statistics and correlations. Tuberculosis and Lung Diseases, 96(12), 9-17. (In Russ.). DOI: 10.21292/2075-1230-2018-96-12-9-17

Yakovlev A.A., Musatov V.B., Savchenko M.A. (2015). Causes of death among HIV infected patients receiving antiretroviral therapy. HIV Infection and Immunosuppressive Disorders, 7(1), 84-89. (In Russ.). DOI: https://doi.org/10.22328/2077-9828-2015-7-1-84-89

World Health Organization (2019). Global tuberculosis report. URL: https://apps.who.int/iris/bitstream/handle/10665/329368/9789241565714-eng.pdf?ua=1

Pokrovskiy V. (2014). HIV epidemic in Russia and neighbouring countries. Journal of the International AIDS Society, 17, 19502. DOI: https://DOI.org/10.7448/IAS.17.4.19502 